\title{
Adipogenesis as a Potential Anti-Obesity Target: A Review of Pharmacological Treatment and Natural Products
}

This article was published in the following Dove Press journal: Diabetes, Metabolic Syndrome and Obesity: Targets and Therapy

\author{
Jelena Jakab $\mathbb{D}^{1,2}$ \\ Blaženka Miškić ${ }^{2,3}$ \\ Štefica Mikšić ${ }^{2}$ \\ Brankica Juranić ${ }^{2,4}$ \\ Vesna Ćosić ${ }^{2}$ \\ Dragan Schwarz ${ }^{2,5}$ \\ Aleksandar V̌̌ev ${ }^{2}$ \\ 'Faculty of Medicine, Josip Juraj \\ Strossmayer University of Osijek, Osijek, \\ Croatia; ${ }^{2}$ Faculty of Dental Medicine and \\ Health Osijek, Josip Juraj Strossmayer \\ University of Osijek, Osijek, Croatia; \\ ${ }^{3}$ Department of Internal Medicine, \\ General Hospital "Dr. Josip Benčević", \\ Slavonski Brod, Croatia; ${ }^{4}$ Department of \\ Cardiology, University Hospital Osijek, \\ Osijek, Croatia; ${ }^{5}$ Special Hospital \\ Radiochirurgia Zagreb, Zagreb, Croatia
}

Correspondence: Jelena Jakab Faculty of Medicine, Josip Juraj Strossmayer University of Osijek, Crkvena 2I, Osijek 3I 000, Croatia $\mathrm{Tel}+385912241502$

Email jelena.jakab@fdmz.hr

\begin{abstract}
Obesity is recognized as a severe threat to overall human health and is associated with type 2 diabetes mellitus, dyslipidemia, hypertension, and cardiovascular diseases. Abnormal expansion of white adipose tissue involves increasing the existing adipocytes' cell size or increasing the number through the differentiation of new adipocytes. Adipogenesis is a process of proliferation and differentiation of adipocyte precursor cells in mature adipocytes. As a key process in determining the number of adipocytes, it is a possible therapeutic approach for obesity. Therefore, it is necessary to identify the molecular mechanisms involved in adipogenesis that could serve as suitable therapeutic targets. Reducing bodyweight is regarded as a major health benefit. Limited efficacy and possible side effects and drug interactions of available anti-obesity treatment highlight a constant need for finding novel efficient and safe anti-obesity ingredients. Numerous studies have recently investigated the inhibitory effects of natural products on adipocyte differentiation and lipid accumulation. Possible anti-obesity effects of natural products include the induction of apoptosis, cell-cycle arrest or delayed progression, and interference with transcription factor cascade or intracellular signaling pathways during the early phase of adipogenesis.
\end{abstract}

Keywords: adipogenesis, transcriptional cascades, signaling pathways, anti-obesity treatment, bioactive molecules

\section{Introduction}

According to the World Health Organization, 39\% of adults are overweight, and $13 \%$ are obese globally. ${ }^{1}$ Obesity has nearly tripled since 1975 and is predicted to triple by $2030 .^{2}$ Obesity poses a severe threat to overall human health due to its close association with a cluster of pathological entities globally designated as metabolic syndrome, including type 2 diabetes mellitus (T2DM), dyslipidemia, hypertension, and cardiovascular diseases. ${ }^{3}$ Obesity is also associated with increased oxidative stress levels due to excessive production of reactive oxygen species (ROS) and dysfunctional antioxidant systems. Adipose tissue is an important energy store and essential regulator of energy balance, but also an active endocrine organ that secretes numerous bioactive peptides and proteins called adipokines. ${ }^{4}$ Adipokines generate ROS, reduce the antioxidant capacity, and stimulate the production of pro-inflammatory cytokines such as interleukin $1 \beta$ (IL-1 $\beta$ ) and 6 (IL-6), and tumor necrosis factor-alpha (TNF- $\alpha$ ), causing an increase in oxidative stress levels. Thus, obesity induces oxidative stress via low-grade chronic 
inflammation, but also through other mechanisms such as mitochondrial and peroxisomal oxidation of fatty acids and over-consumption or altered $\mathrm{O} 2$ metabolism. ROS induces endothelial dysfunction, decreases vasodilator and increases contractile factors, and damages cell structures, causing atherosclerosis, heart failure, hepatic steatosis, and cancer. ${ }^{5}$ The link between chronic inflammation and cancer lies in tumor promoters' ability to recruit inflammatory cells and stimulate them to generate ROS. Significant damage may occur to cell structure and functions, inducing somatic mutations, and neoplastic transformation. Oxidative stress causes cancer initiation and progression by interacting with the initiation (gene mutations and structural alterations of the DNA), promotion (abnormal gene expression, blockage of cell- to cell communication, modification of second messenger systems), and progression (further DNA alterations) of cancer. There is a significant contribution to cancer development of the triad of over-weight/obesity, insulin resistance (IR), and adipocytokines. Some of the effects of obesity in cancer etiopathogenesis comprise inducing hyperinsulinemia and subclinical chronic low-grade inflammation and oxidative stress and causing alterations in adipocytokine pathophysiology, and sex hormones biosynthesis. ${ }^{6}$

In light of the current COVID-19 pandemic, it is important to emphasize an association between obesity and infectious diseases, especially pulmonary infections. Obesity increases the risk of hospitalization and admission to intensive care units, in addition to greater severity of the disease and higher mortality in COVID-19 patients. In patients under the age of 60 , obesity is the main predictor of severe symptoms and doubles the risk of being admitted to critical care. ${ }^{7}$ Underlying mechanisms include obesityrelated comorbidities (T2DM, cardiovascular and renal diseases), immune system impairments facilitating a systemic diffusion of infection, increased type 2 inflammation with effects on the lung parenchyma, raised IL-6 levels, and abnormal secretion of adipokines and cytokines inducing low-grade inflammation. ${ }^{8}$

Given the obvious physical constraints and associated psychological stress, as well as the risk of obesity-related health complications, reducing body weight is regarded as a major health benefit. The etiologic-mechanistic perspective of obesity is still poorly understood, and there are very few effective pharmacological approaches for obesity prevention. The etiology of obesity involves an interaction between genetic and environmental factors, the latter being the main reason for the increase in the global prevalence of obesity. Changes in lifestyle and dietary habits have resulted in an outbreak of the obesity pandemic over the last decades. Obesity results from an imbalance between energy intake and expenditure. The increased caloric intake from diets high in saturated fats, sugar, and processed foods, together with reduced physical activity, results in an energy imbalance. ${ }^{9}$

\section{Adipose Tissue and Adipogenesis}

Excess energy is stored in the form of lipids in adipocytes, and an excessive accumulation of adipose tissue characterizes obesity. There are two types of adipose tissues, brown (BAT) and white (WAT). BAT is mainly responsible for non-shivering thermogenesis in response to cold stress or $\beta$-adrenergic stimulus, while WAT plays a crucial role in lipid homeostasis and maintaining energy balance. ${ }^{10}$ Abnormal expansion of WAT associated with obesity involves increasing the cell size of the existing adipocytes (hypertrophy) or increasing the number through differentiation of new adipocytes (hyperplasia). ${ }^{11}$ Under normal circumstances, excess energy does not damage the organism as long as it is efficiently stored in the adipose tissue. However, when amounts of fat exceed the adipose tissue's storage capacity and overwhelm adipose tissue's functional capacity, fat begins to deposit ectopically in other metabolically relevant organs, such as the liver, skeletal muscle, kidney, and pancreas. ${ }^{12}$ With obesity progression, adipose tissue becomes inflamed and fibrotic, worsening the dysfunction and decreasing the WAT's metabolic flexibility, leading to the development of metabolic abnormalities, such as dyslipidemia and IR. ${ }^{13}$ Hypertrophic WAT expansion due to increased white adipose cells, macrophage infiltration, and fibrosis disrupt hormonal balance. The release of inflammatory cytokines and adipokines alters the normal energy homeostasis and causes metabolic syndrome. $^{14}$

Adipocyte hyperplasia, also known as adipogenesis, is a process of proliferation and differentiation of adipocyte precursor cells in mature adipocytes. ${ }^{15}$ It is a key process in determining the number of adipocytes, occurring mainly during childhood and adolescence, further determining the lipid-storing capacity of adipose tissue and fat mass in adults. ${ }^{10}$ Therefore, the regulation of size and number of adipocytes might be a possible therapeutic approach for obesity, and it is important to understand the molecular mechanisms of adipose tissue formation and alterations in obesity. Identifying potential adipogenic molecular targets 
susceptible to modulation by external factors can utilize adipogenesis regulation to control or reverse obesity.

This review focuses on available conventional medicine and natural products to prevent or treat obesity by targeting adipogenesis and discussing potential adipogenesis mechanisms suitable for the therapeutic approach.

\section{Molecular Regulators of Adipogenesis as Potential Therapeutic Targets}

Adipogenesis is a complex multi-step process through which preadipocytes convert into mature, lipid-containing adipocytes. It is essential to renew adipose tissue and support adipose dynamics since approximately $10 \%$ of our body's fat cells are regenerated each year. ${ }^{16}$ Two adipogenesis phases have been recognized: pluripotent stem cells' commitment to a unipotent preadipocyte and terminal differentiation of preadipocytes into mature adipocytes. When pluripotent stem cells commit to the adipocyte lineage, they lose the ability to differentiate into other cell types and undergo morphological and functional changes due to numerous signaling pathways, transcription factors, and genes. ${ }^{17}$

Differentiation of 3T3-L1 preadipocyte fibroblast clonal cell line into mature fat cells is one of the most commonly used in vitro models to study adipose tissue biology. After induction of differentiation by proadipogenic factors, this line shows the morphology and gene expression of white adipose tissue. ${ }^{18}$ Adipogenesis in vitro occurs in four steps: growth arrest, mitotic clonal expansion (MCE), early differentiation, and terminal differentiation. ${ }^{19}$ After contact inhibition and growth arrest of post-confluent 3T3-L1 preadipocytes, the differentiation is induced by hormonal stimulation with insulin, dexamethasone, and 1-methyl-3-isobutyl-xanthine (IBMX). ${ }^{20}$ Dexamethasone and IBMX directly induce genes responsible for the expression of adipogenic transcription factors, while insulin stimulates cells to take up glucose and store it in the form of triacylglycerol. ${ }^{21,22}$ After adipogenic cocktail-induced differentiation, cells re-enter the cell cycle synchronously and undergo one or two mitosis cycles, regarded as MCE, when an irreversible commitment to differentiation occurs. ${ }^{23} \mathrm{MCE}$ is a crucial prerequisite for the differentiation process - if cells are prevented from entering the $\mathrm{S}$ phase during MCE, the expression of transcription factors and regulators of adipogenesis will not occur, and differentiation will be blocked. $^{24}$ Cell mitosis is required to unwind DNA allowing transcription factors to access regulatory elements in genes involved in the differentiation process. Therefore, sustaining cells at one point in the cell cycle might be an effective way to block adipogenesis. Cyclindependent kinase (CDK) complexes with cyclin D and $\mathrm{E}$ are essential for retinoblastoma $(\mathrm{Rb})$ phosphorylation and the reentry into the cell cycle. CDK inhibitors such as $\mathrm{p} 21 \mathrm{CIP}$ and $\mathrm{p} 27 \mathrm{KIP} 1$ are associated with cell-cyclearrested preadipocytes, while their degradation results in G1/S phase progression. ${ }^{25}$ During early differentiation, a morphological rounding of preadipocytes occurs, and the terminal phase of differentiation is characterized by lipid synthesis and transport, adipocyte-specific proteins secretion, insulin-associated metabolic processes activation, and mature lipid-loaded adipocytes morphology (Figure 1). ${ }^{26}$

Adipogenesis is strictly regulated by the transcriptional cascade and signaling pathways (Figure 1). During the early stages of differentiation, transient high expression of CCAAT/enhancer-binding proteins (C/EBP), $\mathrm{C} / \mathrm{EBP} \delta$, and $\mathrm{C} / \mathrm{EBP} \beta$ occur. During the intermediate stage of adipogenesis, $\mathrm{C} / \mathrm{EBP} \beta / \delta$ stimulate $\mathrm{C} / \mathrm{EBP} \alpha$ and peroxisome proliferator-activated receptor $\gamma(\operatorname{PPAR} \gamma)$, key transcription factors of adipogenesis. PPAR $\gamma$ and $\mathrm{C} / \mathrm{EBP} \alpha$ cooperatively promote differentiation and induction of several adipocyte-specific genes, including lipoprotein lipase (LPL), adipocyte protein 2 (aP2), fatty acid synthase (FAS), and perilipin in the terminal stage of differentiation (Figure 1). ${ }^{27}$

\section{Transcription Factors in Adipogenesis CCAAT/Enhancer-Binding Proteins}

$\mathrm{C} / \mathrm{EBP} \beta$ and $\mathrm{C} / \mathrm{EBP} \delta$ are the first transcription factors induced immediately after stimulation by adipogenic hormonal cocktails and play an important role in directing the differentiation process. The localization of $\mathrm{C} / \mathrm{EBP} \beta$ to the nucleus facilitates DNA-binding activity and leads to phosphorylation and transcriptional activation of PPAR and C/ $\mathrm{EBP}^{2}{ }^{28}$ Decreased nuclear localization of $\mathrm{C} / \mathrm{EBP} \beta$ and disrupted DNA-binding activity inhibits $\mathrm{C} / \mathrm{EBP} \alpha$ and PPAR $\gamma$ gene expression, thereby suppressing adipogenesis. In $\mathrm{C} / \mathrm{EBP} \beta$-null mice, adipogenesis is severely impaired, meaning that $\mathrm{C} / \mathrm{EBP} \alpha$ and PPAR $\gamma$ in the absence of $\mathrm{C} / \mathrm{EBP} \beta$ are not sufficient for complete differentiation. ${ }^{29}$ Therefore, $\mathrm{C} / \mathrm{EBP} \beta$ inhibition could be one potential target for preventing or treating obesity, as decreasing early adipogenic transcription markers inhibits subsequent transcriptional cascade and suppresses terminal adipogenic differentiation. 

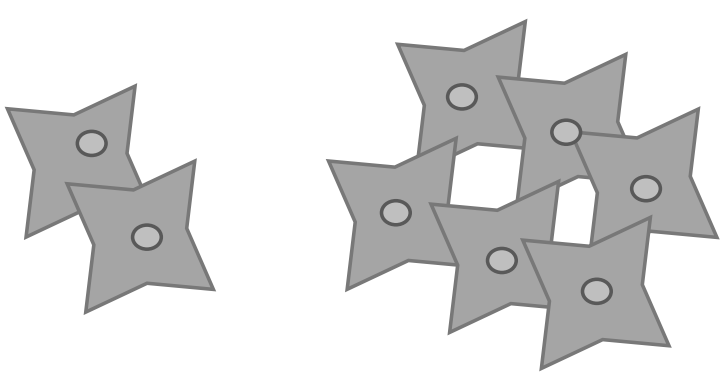

Preadipocytes $\longrightarrow \quad$ Mitotic clonal expansion
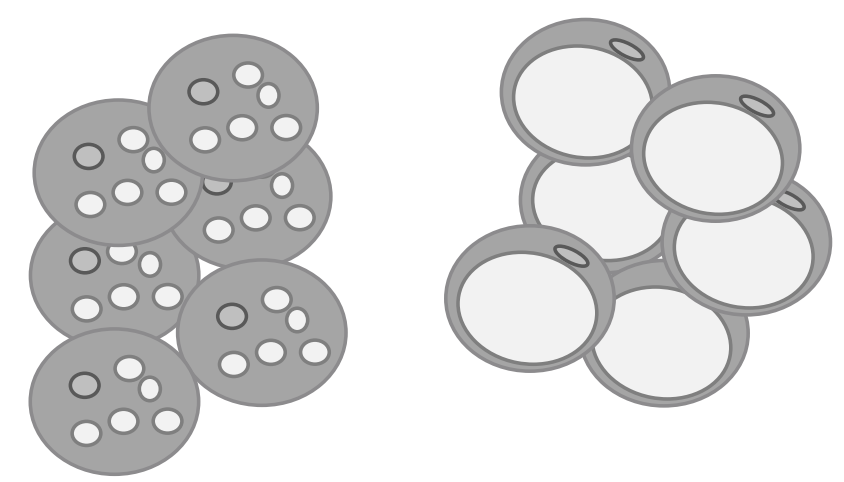

Terminal differentiation

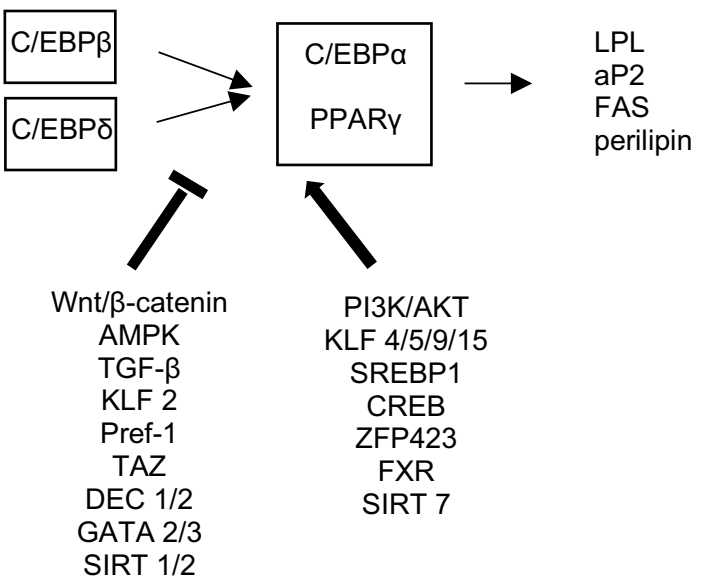

Figure I Stages and molecular regulation of adipogenesis.

Some C/EBP family members, such as the C/EBP homologous protein (CHOP), form inactive heterodimers with $\mathrm{C}$ / $\mathrm{EBP} \alpha$ and $\mathrm{C} / \mathrm{EBP} \beta$. Heterodimers cannot bind DNA and function as a dominant-negative inhibitor of gene transcription, suppressing adipocyte differentiation. ${ }^{30}$ The direct inhibition of $\mathrm{C} / \mathrm{EBP} \beta$ activity by increasing the CHOP level can lead to PPAR $\gamma$ suppression and adipogenesis prevention.

\section{Peroxisome Proliferator-Activated Receptor $\gamma$}

PPAR $\gamma$ controls gene network expression in adipogenic differentiation, glucose and lipid metabolism, inflammation, and other physiological processes. Protein isoform PPAR $\gamma 2$ is abundantly expressed in the adipose tissue, and it is essential for adipogenesis and the maintenance of the differentiated state. Activation of PPAR $\gamma$ increases the number of small and insulin-sensitive adipocytes and up-regulates adiponectin, improving insulin sensitivity in the liver and muscle. ${ }^{31}$ Given its crucial role in adipogenesis, PPAR $\gamma$ has been a critical target in developing antiobesity drugs. PPAR $\gamma$ binds to specific DNA sequences as a heterodimer with the retinoid $\mathrm{X}$ receptor (RXR) and regulates target genes' transcription. ${ }^{32}$ The activity of PPAR $\gamma$ can be regulated by binding agonist ligands, such as thiazolidinediones, which improve IR, enhance glucose uptake, and lower glucose concentration. They also exert anti-inflammatory effects, which is potentially important in treating obesity and T2DM. ${ }^{33}$ In vitro studies showed that insulin and corticosteroids induce the expression of PPAR $\gamma$ mRNA, ${ }^{34}$ whereas TNF $\alpha$ down-regulates the expression of PPAR $\gamma .{ }^{35}$ On the other hand, unliganded PPAR/RXR heterodimers interact with co-repressor molecules to repress the transcription of target genes, which means that the investigation of PPAR antagonists may be a logical approach for research of anti-obesity medication.

\section{Signaling Pathways in Adipogenesis}

Several signaling pathways are included in the adipogenesis process, such as the insulin and IGF-1-activated phosphoinositide 3-kinase/protein kinase B (PI3K/AKT), mitogen-activated protein kinase/extracellular signalregulated kinase (MAPK/ERK) pathways, Wnt/ $\beta$-catenin 
signaling, AMP-activated protein kinase (AMPK) pathway, Hedgehog $(\mathrm{Hh})$ signaling, and bone morphogenic protein (BMP) signaling pathways.

\section{PI3K/AKT and MAPK/ERK Signaling Pathways}

The hormonal induction cocktail activates PI3K/AKT and MAPK/ERK pathways during the early stage of differentiation. Intracellular MAPK signaling is important for regulating cell proliferation and differentiation, while ERK activation is essential for the induction of MCE and adipogenesis. ${ }^{36}$ In 3T3-L1 preadipocytes, inactivation of the PI3K/AKT pathway inhibits adipogenesis, while activation of this pathway contributes to adipocyte differentiation. ${ }^{37}$ However, different studies showed that MAPK pathways phosphorylate PPAR and reduce its transcriptional activity and that activation of MAPK antagonizes 3T3-L1 adipocytic differentiation. ${ }^{38}$ Clear elucidation of MAPK/ERK signaling pathway effects on adipogenesis could provide another potential target of adipose tissue formation in obesity.

\section{Wnt/ $\beta$-Catenin Signaling Pathways}

Wnt signaling maintains preadipocytes in an undifferentiated state by inhibiting PPAR $\gamma$ and $\mathrm{C} / \mathrm{EBP} \alpha$. In 3T3-L1 preadipocytes, Wnt induction inhibits adipogenesis by dysregulation of the cell cycle and blocking PPAR $\gamma$ and $\mathrm{C} / \mathrm{EBP} \alpha$ expression, while disruption of Wnt signaling leads to adipogenic differentiation. ${ }^{39}$ After adipogenesis induction, phosphorylated glycogen synthase kinase $3 \beta$ (GSK3 $\beta$ ) suppresses Wnt signaling by the degradation of $\beta$-catenin. Wnt signaling promotes $\beta$-catenin stabilization and nuclear translocation, causing the downstream inhibition of $\mathrm{C} / \mathrm{EBP} \alpha$ and PPAR $\gamma .{ }^{36}$ The stabilization and nuclear localization of $\beta$-catenin, as an important step in adipogenesis inhibition, might be a potential therapeutic target for the prevention/treatment of obesity.

\section{AMP-Activated Protein Kinase Signaling Pathway}

AMPK is a serine/threonine-protein kinase activated by phosphorylation of the $\alpha$ subunit when cellular ATP levels are decreased. When phosphorylated, AMPK promotes catabolic pathways such as fatty acid oxidation and inhibits energy-consuming pathways such as fatty acid synthesis. ${ }^{10}$ Since adipogenesis can be considered an energy-consuming process, AMPK acts as a negative regulator of adipogenesis and can be considered a target for the treatment of obesity. ${ }^{40}$ The anti-adipogenic effects of AMPK are mediated by suppressing PPAR $\gamma$ via positive regulation of p38 MAPK, which promotes PPAR phosphorylation and inhibits its transcriptional activity. ${ }^{41}$ In the 3T3-L1 cell line, AMPK activation inhibits $\mathrm{MCE}$ and the expression of $\mathrm{C} / \mathrm{EBP} \alpha$, $\operatorname{PPAR} \gamma$, and late adipogenic markers. ${ }^{42}$

\section{Bone Morphogenic Protein Signaling Pathway}

BMPs are members of the transforming growth factor- $\beta$ (TGF- $\beta$ ) superfamily and display varied effects on adipogenesis, depending on BMP's concentration and type. Generally, TGF- $\beta$ inhibits preadipocyte differentiation in vitro by interacting with $\mathrm{C} / \mathrm{EBP}$ and repressing its transcriptional activity. ${ }^{43}$ TGF- $\beta$ phosphorylates Smad 2 and Smad 3, and BMP subfamily phosphorylates R-Smads (Smad 1, 5, 8). Phosphorylated R-Smad binds to Smad 4, facilitating the migration into the nucleus and transcriptional activity of the Smad protein. BMPs can also activate the p38MAPK signaling cascade, which regulates mitochondrial biogenesis and insulindependent glucose uptake. $^{44}$ Some findings suggest a cross-talk between BMP signaling and PPAR $\gamma$ action, which may be explained by the ability of BMP-2 to upregulate PPAR $\gamma$ expression. ${ }^{45}$

\section{Hedgehog Signaling Pathway}

Activation of the Hh signaling pathway impairs adipogenesis and lipid accumulation. This pathway is down-regulated during human adipocyte differentiation. Hh protein inhibits adipogenesis by reducing the expression of $\mathrm{C} / \mathrm{EBP} \alpha, \operatorname{PPAR} \gamma$, and $\mathrm{aP} 2$, whereas inhibition of Hh signaling using increases adipogenic differentiation in 3T3-L1. ${ }^{46}$ Nearly complete inhibition of adipocyte differentiation is shown by Oil Red O staining, a 40\% reduction in triglyceride accumulation, a $50 \%$ decrease of adipocyte marker expression, and upregulation of preadipocyte factor-1 (Pref-1). ${ }^{47}$ Adipocyte differentiation inhibition occurs even after one hour of $\mathrm{Hh}$ stimulation concomitant with adipogenic induction, suggesting that $\mathrm{Hh}$ signaling is maintained several days after its stimulation or controls critical early steps of differentiation. ${ }^{48}$

\section{Other Regulators of Adipogenesis}

\section{Positive Regulators of Adipogenesis}

Several factors are identified as positive regulators of adipogenesis, such as the Kruppel-like factor family (KLF), sterol regulatory element-binding protein 1 (SREBP1), cyclic AMP response element-binding protein (CREB), zinc finger protein 423 (ZFP423), and farnesoid $\mathrm{X}$ receptor (FXR). Decreasing adipogenic transcription factors might be a good approach to inhibit adipose tissue development during obesity progression. 
Several KLF zinc-finger transcription factors are induced during adipogenesis in 3T3-L1 preadipocytes. ${ }^{31}$ KLF4 is an early marker of adipogenesis, expressed within the first $30 \mathrm{~min}$ after exposure of $3 \mathrm{~T} 3-\mathrm{L} 1$ cells to an adipogenic cocktail. ${ }^{49} \mathrm{KLF} 5$ is induced by $\mathrm{C} / \mathrm{EBP} \delta / \beta$ during the early stages of adipogenesis, binds directly to the PPAR $\gamma 2$ promoter, and cooperates with C/EBPs. ${ }^{22}$ Inhibition of KLF9, which is usually up-regulated during the middle stage of differentiation and binds directly to the PPAR $\gamma 2$ promoter, inhibits adipogenesis. ${ }^{50}$ Inhibition of KLF15 also leads to reduced expression of PPAR $\gamma$, blocking adipogenesis in 3T3-L1 preadipocytes. ${ }^{51}$ SREBP1 regulates the expression of FAS and LPL and increases the activity of PPAR $\gamma$, augmenting adipogenesis. ${ }^{52}$ The expression of CREB is stimulated by the adipogenic cocktail, which can be sufficient to initiate lipid accumulation and the expression of PPAR $\gamma$ and fatty acid-binding protein (FABP). ${ }^{53}$ ZFP423 can promote adipogenesis of nonadipogenic NIH 3T3, while its inhibition in 3T3-L1 cells blocks PPAR $\gamma$ expression and adipogenic differentiation. ${ }^{54}$ Furthermore, in bovine stromal vascular cells, ZFP423 increases lipid accumulation and expression of PPAR $\gamma$ and $\mathrm{C} / \mathrm{EBP} \alpha{ }^{55} \mathrm{FXR}$ is a nuclear hormone receptor that promotes adipocyte differentiation by partially inducing PPAR $\gamma 2$ and $\mathrm{C} / \mathrm{EBP} \alpha$ expression. After RXR heterodimerization, the agonist ligand activates FXR, which then binds to FXR response elements and regulates target gene expression. ${ }^{56}$ Therefore, investigating FXR activity inhibition by antagonist ligands for FXR can be considered for fighting obesity.

\section{Negative Regulators of Adipogenesis}

On the other hand, high and sustained levels of KLF2, Pref-1, transcriptional-coactivator with PDZ-binding motif (TAZ), differentiated embryo chondrocyte (DEC), GATA transcription factors, and histone deacetylase Sirtuin 1 (SIRT1) inhibits adipogenesis and keeps cells at the preadipocyte stage. Targeting these factors is a potentially effective therapeutic approach to intervene in obesity.

KLF2 represses adipogenesis by inhibition of PPAR $\gamma, \mathrm{C} /$ EBP $\alpha$, and SREBP1 expression in 3T3-L1 preadipocytes. ${ }^{57}$ Pref-1 is highly expressed in preadipocytes and inhibits adipocyte differentiation by preventing lipid accumulation and expression of PPAR $\gamma, \mathrm{C} / \mathrm{EBP} \alpha$ FAS, and aP2.$^{58} \mathrm{TAZ}$ suppresses adipocyte differentiation via PPAR $\gamma$ activity repression, and its diminished expression enhances adipogenic differentiation. ${ }^{59}$ DEC 1 and 2 are abundantly expressed in preadipocytes and down-regulated during adipogenesis. They inhibit the transcriptional activity of $\mathrm{C} /$ $\mathrm{EBP} \beta / \alpha{ }^{60}$

The GATA family of transcription factors play important roles in a variety of biological processes, including adipogenesis. GATA-2 and GATA-3 are predominantly present in white adipose tissue and significantly contribute to adipocyte differentiation regulation. Their constitutive expression inhibits adipogenesis by trapping cells in the preadipocyte stage. This effect could be a result of direct suppression of PPAR $\gamma$ expression through PPAR $\gamma$ promoter or the formation of protein complexes with $\mathrm{C} / \mathrm{EBP} \alpha$ and $\mathrm{C} / \mathrm{EBP} \beta{ }^{61}$ GATA2 and GATA3 are down-regulated during the terminal differentiation process, and their defective expression is associated with obesity. ${ }^{62}$ These findings indicate the crucial role of GATA transcriptional factors during terminal adipocyte differentiation and their potential as targets for the therapeutic intervention of obesity.

Sirtuins (SIRT) and miRNAs are recently discovered modulators of adipogenesis with various effects on adipocyte differentiation progression. SIRT1 is an NAD+-dependent nuclear deacetylase that acts as a negative modulator of adipogenesis in the 3T3-L1 cell line. SIRT1 attenuates adipogenesis by interacting with its cofactors, nuclear receptor co-repressor (NCoR), and the silencing mediator of retinoid and thyroid hormone receptors (SMRT). ${ }^{63}$ SIRT1 binds to the same DNA sequences as PPAR $\gamma$, acting as its corepressor. SIRT1 can also induce BAT-specific genes while repressing visceral WAT genes and induce the expression of genes involved in fatty acid oxidation. ${ }^{64}$ Additionally, SIRT2 exerts an inhibitory effect on adipogenesis by FOXO1 deacetylation and subsequent PPAR $\gamma$ transcriptional activity repression. ${ }^{65}$ On the other hand, SIRT7 was shown to be important for PPAR expression and proper adipocyte differentiation. Therefore, activation of SIRT 1 and 2 or inhibition of SIRT7 during adipogenesis could provide a novel therapeutic strategy for obesity. However, it is difficult to find a single compound that would activate some SIRTs while inhibiting others, and it is hard to obtain tissue action specificity.

miRNAs are small non-coding RNAs that bind to specific target mRNAs to promote their degradation or prevent their translation. ${ }^{66}$ They have recently been in the focus of obesity research as potent regulators of the posttranscriptional expression of crucial genes in adipogenesis. Some miRNAs (miR-21, miR-29b, miR-144-3p, miR148a, miR-210, miR-205-5p) enhance adipogenesis by interfering with the expression of anti-adipogenic signaling pathways (TGF- $\beta$, TNF- $\alpha$, Wnt, co-repressors of $\mathrm{C} /$ 
$\mathrm{EBP} \alpha)$. On the other hand, some miRNAs inhibit adipocyte differentiation (miR-27a and b, miR-31, miR-128-3p, miR-130a and b, miR- 146a-5p, miR-155, miR-540) by directly targeting C/EBPs and PPAR $\gamma .{ }^{11}$ Additionally, some miRNAs, such as miR-30a, play an important role in mature WAT biology. Lower levels of miR-30a in subcutaneous WAT correlate with IR, while its overexpression improves insulin sensitivity and energy expenditure. ${ }^{67}$ miR-30a also exerts an anti-inflammatory effect by targeting signal transducer and activator of transcription 1 (STAT1). Moreover, miR- 103 and miR-107 can regulate the size of the preadipocyte population in WAT, directly suppressing the expression of Wnt3a, an activator of the Wnt/ $\beta$-catenin pathway, thus promoting stress-mediated apoptosis in preadipocyte. ${ }^{68}$ In addition, the miR-128 was found to be one of the most upregulated miRNAs in hypoxic 3T3- L1 adipocytes. It directly targets the 30-UTR sequence of the INSR gene, reducing the expression of plasma membrane tyrosine kinase receptor protein INSR through which insulin exerts its biological effects. It was shown that obesity-induced hypoxia increases the expression of miR-128, which then negatively affects INSR mRNA and protein expression levels in adipose tissue of both obese patients and high-fat diet-fed mice, correlating with the decrease in INSR expression. This result was consistent with the miR-128 expression level in hypoxic 3T3-L1 adipocytes. ${ }^{69}$

miRNAs could be used as clinical biomarkers to predict the development of obesity and related complications or to assess therapeutic anti-obesity strategies' effectiveness due to the normalization of miRNAs levels upon acute weight loss. ${ }^{70}$ miRNAs can also regulate SIRTs activity, so there is a possibility to modify the action of SIRTs by specific miRNAs for treating obesity. miR-34a, miR-146b, and miR-181a are negative regulators of SIRT1, and SIRT7 is a metabolic target for miR-93, a negative regulator of adipogenesis. ${ }^{71}$ However, safely targeting specific tissue and avoiding side effects using miRNA therapeutics is still a challenge.

\section{Therapeutic Approach - Conventional Medicine with Effects on Adipogenesis}

Obesity treatment aims not only for weight reduction but also a reduction of obesity-related complications. The most commonly used therapeutic strategies include lifestyle modification, calorie restriction combined with increased physical activity, while bariatric surgery is limited to morbidly obese patients. ${ }^{72}$ Long-term effects of lifestyle modification are frequently disappointing, with $90 \%$ of the people returning to their original weight within two to five years. ${ }^{36}$ Although anti-obesity drugs might be a promising solution, their limited efficacy, together with possible side effects and drug interactions, highlights a constant need to find novel, efficient, and safe anti-obesity ingredients. For that purpose, it is necessary to identify pathogenic molecular mechanisms that could serve as suitable therapeutic targets.

To observe available medications for treating obesity, one has to bear in mind the connection of obesity with metabolic syndrome and the risk for developing other chronic diseases such as T2DM and cardiovascular disease. Although different pathophysiological mechanisms lead to metabolic syndrome, it is associated with obesity through dysfunction of adipose tissue as the main contributor to obesity and subsequent complications. Disturbed metabolic homeostasis leads to visceral obesity, atherogenic dyslipidemia, arterial hypertension, and IR. ${ }^{73}$ Since adipose tissue dysfunction mainly presents as obesity and dyslipidemia, currently approved medications for obesityrelated conditions also affect adipose tissue functions and adipogenesis, and knowing the underlying mechanisms of these effects has great clinical value.

\section{Statins}

Statins are 3-hydroxy-3-methyl-glutaryl-coenzyme A (HM $\mathrm{G}-\mathrm{CoA}$ ) reductase inhibitors that inhibit the conversion of HMG-CoA to mevalonic acid in a competitive manner. They lower total cholesterol, LDL cholesterol, and triglyceride levels while increasing HDL cholesterol levels. ${ }^{74}$ In adipose tissue, they enhance lipolysis and decrease lipid accumulation in mature adipocytes, increase mRNA LPL expression in preadipocytes, preventing adipocyte hypertrophy by increasing the number of small adipocytes. ${ }^{75}$ Their effect on adipogenesis in vitro goes through down-regulation of $\mathrm{C} / \mathrm{EBP} \alpha$, PPAR $\gamma$, SREBP1, leptin, FABP4, and adiponectin. ${ }^{76}$

\section{Fibrates}

Fibrates increase LPL and fatty acids hepatic uptake while reducing hepatic triglyceride production and increasing HDL cholesterol levels. Fibrates act as synthetic ligands for PPAR $\alpha$ increasing fatty acids hepatic B-oxidation, LPL activity, and VLDL clearance. ${ }^{77}$ Through PPAR $\alpha$ stimulation and upregulation of fatty acid oxidation enzymes in adipose tissue, fibrates can decrease body weight and reduce plasma leptin concentration. ${ }^{76}$ They also can 
increase energy expenditure and even induce the browning of WAT adipocytes. ${ }^{78}$ Binding directly to PPAR $\alpha$, fibrates induce adipogenesis and forming small and numerous lipid droplets in adipocytes. ${ }^{79}$

\section{Niacin}

Niacin is the most effective for increasing HDL levels and decreases total cholesterol, LDL, triglyceride synthesis, and fatty acid re-esterification. ${ }^{80}$ It stimulates adipogenesis throughout increasing PPAR $\gamma, \mathrm{FABP} 4$, adiponectin, and leptin expression in $3 \mathrm{~T} 3-\mathrm{L} 1$ cells. $^{81}$

\section{Metformin}

Metformin is the most commonly used drug to treat T2DM. It suppresses hepatic glucose production and improves adipose tissue metabolism in the liver and muscle, leading to decreased plasma glucose levels. ${ }^{82}$ Metformin reduces lipolysis, increases glucose uptake into skeletal muscle cells, increases intestinal glucose utilization, and improves pancreatic $\beta$-cell survival. ${ }^{83}$ Metformin has a pleiotropic effect in reducing appetite, preventing cardiovascular diseases, improving endothelial function, modulation of inflammation, and cancer prevention. ${ }^{84}$ In addition to all of the above, metformin also leads to weight loss severity, although this effect's mechanism is still unknown. The effect of metformin on endocrine adipose tissue function is still a matter of debate, given the fact that it has been shown more effective in obese patients with TMD2 than in those with lower body mass index. ${ }^{85}$ Metformin is known to act through AMPK, whose activation inhibits adipogenesis in 3T3-L1 cell culture. ${ }^{42}$ Metformin interferes with oxidative phosphorylation in mitochondria and stimulates osteogenic differentiation via AMPK, which is known to promote osteogenic and suppress adipogenic differentiation, although the exact mechanism of this action is unknown. ${ }^{86}$

\section{Liraglutide}

Liraglutide was firstly approved as an antidiabetic drug and, but in higher doses, it showed anti-obesity effects. As a glucagon-like peptide 1 receptor agonist, it reduces food ingestion and appetite and can also slow gastric emptying while showing anti-adipogenic, antilipogenic, and prolipolytic effects in human mature adipocytes. ${ }^{70}$ Liraglutide reduces total fat mass and can change fat depots' regional distribution. ${ }^{87}$ Downregulation of AKT and PI3K pathways and upregulation of AMPK decreases lipogenesis in WAT, reducing lipid storage. ${ }^{88}$ Liraglutide also increases energy expenditure by increased thermogenesis. ${ }^{89}$ In 3T3-L1 cells, it induces $\operatorname{PPAR} \gamma, \mathrm{C} / \mathrm{EBP} \beta / \delta$, and modulates $\mathrm{ERK} 1 / 2$,
PKCB, and AKT pathways. ${ }^{90}$ However, in human adipocytes, liraglutide exerts an anti-adipogenic effect through the cAMP pathway. Binding directly to GLP-1R decreases adipogenesis and lipogenesis-related genes while increasing the expression of the lipolytic ones. ${ }^{91}$

\section{Bioactive Molecules with Effects on Adipogenesis}

Natural products have played an important role in alleviating a number of health problems throughout history and remained a large portion of pharmaceutical agents nowadays. For example, over $60 \%$ of the current anticancer drugs were derived from natural sources. ${ }^{92}$ Biomolecules serve as models for the preparation of efficacious analogs, which results in more effective and less toxic targeted therapies. Furthermore, natural products help identify bioactive compounds as a basis for developing anti-inflammatory drugs. The best example is polyphenolics that modulate the inflammatory pathways and serve as biomarkers that can be used to prepare therapeutic agents for treating inflammatory disorders. ${ }^{93}$ Natural products have also become a part of our daily diet. Moreover, some antidiabetic agents, such as widely used drug metformin, have been developed from natural sources. Many plants are used traditionally as a part of diabetes treatment throughout the world, and their efficacy and safety have been validated through clinical use over the years. They are commonly considered to be less toxic and with fewer side effects than synthetic medicines. ${ }^{94}$ In addition, a variety of natural plants, functional fatty acids, and other natural dietary compounds are ingredients of current anti-obesity products or in consideration as potential ingredients for future anti-obesity products. Active compounds of natural products are mostly derived from plants, including fruits, vegetables, grains, and herbs containing a high amount of phytochemicals, fibers, and unsaturated fatty acids. ${ }^{95}$ Mechanisms of action of natural products include interfering with nutrient absorption, decreasing adipogenesis and increasing thermogenesis, suppressing the appetite, and modifying the intestinal microbiota composition. ${ }^{96}$

Recently, numerous studies have investigated the inhibitory effects of natural products on adipocyte differentiation and lipid accumulation. Possible anti-obesity effects of natural products include the induction of apoptosis, cellcycle arrest or delayed progression, and interference with transcription factor cascade or intracellular signaling pathways during the early phase of adipogenesis. The 
following sections briefly discuss some of the natural products, while others are listed in Table 1, grouped by their mechanism of action.

\section{Delphinidin}

Delphinidin is an anthocyanin found in pigmented fruits and vegetables with antioxidant, anti-inflammatory, antiatherosclerosis, and anti-cancer bioactivities. It downregulates the expression of adipogenesis and lipogenesis markers, inhibits lipid accumulation, and upregulates fatty acid metabolism gene expression in 3T3-L1 adipocytes. ${ }^{97}$ In addition, the activation of Wnt and nuclear translocation and stabilization of $\beta$-catenin decreases lipid accumulation in 3T3-L1 cells. Additionally, delphinidin up-regulates p21CIP or p27KIP1 expression, decreases C/EBP $\beta$ expression, and suppresses GSK3 $\beta$ expression. $^{98}$

\section{Genistein}

Genistein, an isoflavone found in legumes, by enhancing CHOP blocks the DNA binding and transcriptional activity of $\mathrm{C} / \mathrm{EBP} \beta$ in 3T3-L1 preadipocytes, thus inhibiting protein expression of PPAR $\gamma$ and $\mathrm{C} / \mathrm{EBP} \alpha .{ }^{99}$ Other studies involving 3T3-L1 cells showed that genistein inhibits adipocyte formation through activation of AMPK, induces apoptosis in mature adipocytes, ${ }^{100}$ inhibits the phosphorylation of P38 MAPK, and prevents $\mathrm{C} / \mathrm{EBP} \alpha$ expression. ${ }^{101}$ Genistein also suppresses hormonal-induced proliferation and blocks cell entry into the $\mathrm{S}$ phase and the $\mathrm{S}$ to the $\mathrm{G} 2 / \mathrm{M}$ phase transition. ${ }^{102}$ In primary human adipocytes, genistein inhibited aP2, SREBP 1, and FAS. ${ }^{103}$ In human adipose tissuederived mesenchymal stem cells, adipogenesis inhibition was associated with the $\mathrm{Wnt} / \beta$-catenin signaling pathway through the expression of $\mathrm{Wnt} 3$, adipogenesis inhibitor, the inhibition of Wnt signaling antagonists, and increase of mRNA and protein levels of $\beta$-catenin. ${ }^{104}$

\section{Guggulsterone}

Plant sterol guggulsterone by FXR antagonism exhibits cholesterol-lowering activity and prevents preadipocyte differentiation. ${ }^{52}$ In 3T3-L1 cells, cis-guggulsterone downregulates $\mathrm{PPAR} \gamma 2, \mathrm{C} / \mathrm{EBP} \alpha$, and $\mathrm{C} / \mathrm{EBP} \beta .{ }^{105}$ In addition, the combination of guggulsterone with genistein exerts anti-adipogenic effects more potently than individual compounds. ${ }^{106}$ Recently it was shown that guggulsterone exerts its anti-obesity effects by inducing beiging of adipocytes through mitochondrial biogenesis and an upregulation of UCP1 and cellular oxygen consumption in 3T3-L1 preadipocytes. ${ }^{107}$

\section{Berberine}

Berberine is an isoquinoline derivative alkaloid that stimulates weight loss, increases insulin sensitivity, lowers blood glucose, and improves lipid metabolism. It increases the mRNA expression of adiponectin and decreases the secretion of leptin and resistin. ${ }^{108}$ Although one recent randomized controlled trial reported no change in BMI and body weight, it reported a reduction in hemoglobin $\mathrm{A} 1 \mathrm{C}(\mathrm{HbA} 1 \mathrm{c})$ and triglyceride levels. ${ }^{109}$ During adipogenesis berberine affects PPAR $\gamma$ transcriptional activity, mRNA, and protein levels in 3T3-L1 cells by interfering with the $\mathrm{C} / \mathrm{EBP} \beta$ signal. ${ }^{110}$ Berberine can also increase GATA-2 and GATA-3 mRNA and protein expression in 3T3-L1 cells and reduce expression of PPAR and $\mathrm{C} / \mathrm{EBP} \alpha$ mRNA and weight gain in high-fat diet-induced obese mice. ${ }^{11}$ Other anti-adipogenic mechanisms of berberine include phosphorylation of p38/AMPK, deactivation of PPAR $\gamma,{ }^{112}$ and upregulation of DEC2 mRNA levels. ${ }^{113}$

\section{Curcumin}

Curcumin, a polyphenol from an Asian spice herb Curcuma longa, exerts anti-adipogenic effects through activation of $\mathrm{Wnt} / \beta$-catenin signaling in 3T3-L1 cells. During differentiation, curcumin restores $\beta$-catenin's nuclear translocation suppresses the expression of $\beta$ catenin destruction complex members and increases mRNA levels of cyclin D1. ${ }^{114}$ Other anti-adipogenic mechanisms of curcumin include activating AMPK, downregulating PPAR $\gamma$ transcription, ${ }^{115}$ decreasing phosphorylation of MAPKs, altered abundance or phosphorylation of GSK3 $\beta,{ }^{114}$ upregulation of KLF4 and KLF5, blocking cell entry into the $S$ phase and the $S$ to the $G 2 / M$ phase transition, decreasing $\mathrm{C} / \mathrm{EBP} \beta$ expression and suppressing adipogenic cocktail-induced proliferation. ${ }^{116}$ In vivo study using mice on high fat diet showed that $500 \mathrm{mg} / \mathrm{kg}$ dietary curcumin significantly decreased weight, total body fat and serum cholesterol compared to untreated mice. ${ }^{96}$

\section{Epigallocatechin Gallate}

Green tea polyphenol Epigallocatechin gallate (EGCG) is known to possess antiproliferative, antioxidant, antibacterial, and chemopreventive effects. ${ }^{117}$ Other health benefits induced by green tea extracts include anti-hypertensive and insulin-sensitizing effects. In humans, EGCG exerts antiobesity effects through ghrelin secretion inhibition, adiponectin levels increase, appetite control, nutrient absorption decrease, and adipogenesis inhibition. ${ }^{118}$ It suppresses adipocyte clonal expansion and inhibits adipogenesis in 3T3-L1 
Table I Phytochemicals and Their Effect on Adipocyte Differentiation Process

\begin{tabular}{|c|c|}
\hline Mechanism of Action & Phytochemicals \\
\hline $\begin{array}{l}\text { Suppressing adipogenic cocktail- } \\
\text { induced proliferation }\end{array}$ & $\begin{array}{l}\text { Dehydroleucodine; }{ }^{143} \text { caffeine; }^{144} \\
\text { apigenin; }^{145} \text { rhamnetin; }{ }^{146} \\
\text { fisetin; }{ }^{147} \text { sulforaphane; }{ }^{148} \text { vitisin } \\
\text { A }^{149}\end{array}$ \\
\hline $\begin{array}{l}\text { Increasing the cell population in } \\
\text { the G0/GI phase }\end{array}$ & $\begin{array}{l}\text { Dehydroleucodine; }{ }^{143} \text { apigenin; } ;^{145} \\
\text { sulforaphane; }{ }^{148} \text { vitisin } \mathrm{A} ;^{149} \\
\text { sinigrin; }^{150} \text { bisdemethyoxy- } \\
\text { curcumin;; }{ }^{151} \text { curcumin- } \\
\text { 3,4-dichloro phenylpyrazole; }{ }^{152} \\
\text { ellagic acid; }{ }^{153} \text { oleuropein and } \\
\text { hydroxytrosol }\end{array}$ \\
\hline $\begin{array}{l}\text { Arresting the cell cycle at the GI-S } \\
\text { checkpoint }\end{array}$ & $\begin{array}{l}\text { Curcumin-3,4-dichloro } \\
\text { phenylpyrazole; }{ }^{152} \text { cocoa; }^{155} \text { caffeic } \\
\text { acid phenethyl ester }\end{array}$ \\
\hline $\begin{array}{l}\text { Blocking the cell entry into the } \\
S \text { phase and the } S \text { to } G 2 / \text { mitosis } \\
\text { (M) phase transition }\end{array}$ & $\begin{array}{l}\text { Turmeric; }{ }^{151} \text { piceatannol; } \\
\text { dieckol }^{158}\end{array}$ \\
\hline $\begin{array}{l}\text { Upregulating P2ICIP and/or } \\
\text { p27KIPI expression }\end{array}$ & $\begin{array}{l}\text { Dehydroleucodine; }{ }^{143} \text { caffeine; } ;^{144} \\
\text { apigenin; }{ }^{145} \text { sulforaphane; }{ }^{148} \text { vitisin } \\
\mathrm{A} ;{ }^{149} \text { sinigrin; }{ }^{150} \text { bisdemethyoxy- } \\
\text { curcumin; }{ }^{151} \text { curcumin- } \\
\text { 3,4-dichloro phenylpyrazole; }{ }^{152}\end{array}$ \\
\hline $\begin{array}{l}\text { Decreasing the phosphorylation of } \\
R b\end{array}$ & $\begin{array}{l}\text { Sulforaphane; }{ }^{148} \text { vitisin } A ;{ }^{149} \text { ellagic } \\
\text { acid; }^{153}\end{array}$ \\
\hline $\begin{array}{l}\text { Upregulating mRNA and protein } \\
\text { expressions of cyclin DI }\end{array}$ & Coumestrol ${ }^{159}$ \\
\hline Decreasing C/EBP $\beta$ expression & $\begin{array}{l}\text { Dehydroleucodine; }{ }^{143} \text { apigenin; }{ }^{145} \\
\text { piceatannol; }{ }^{157} \text { dieckol; }{ }^{158} \\
\text { Rehmannia glutinosa }{ }^{160}\end{array}$ \\
\hline $\begin{array}{l}\text { Decreasing C/EBP } \beta \text { centromeric } \\
\text { localization, DNA-binding activity, } \\
\text { and phosphorylation }\end{array}$ & Apigenin; ${ }^{145}$ sinigrin; ${ }^{150}$ \\
\hline $\begin{array}{l}\text { Blocking C/EBP } \beta \text {-induced } \\
\text { expression of PPAR } \gamma\end{array}$ & Retinoic acid $^{161}$ \\
\hline $\begin{array}{l}\text { Decreasing mRNA expression and } \\
\text { activity of PPAR } \gamma\end{array}$ & Piperine $^{162}$ \\
\hline $\begin{array}{l}\text { Antagonizing PPAR } \gamma / \mathrm{R} X \mathrm{R} \alpha \\
\text { heterodimerization }\end{array}$ & 7-chloroarctinone-b $b^{163}$ \\
\hline Suppressing AKT activation & $\begin{array}{l}\text { Dehydroleucodine; }{ }^{143} \text { caffeine; }{ }^{144} \\
\text { sulforaphane; }{ }^{148} \text { bisdemethyoxy- } \\
\text { curcumin;; }{ }^{151} \text { curcumin- } \\
\text { 3,4-dichloro phenylpyrazole; }{ }^{152} \\
\text { cocoa; }^{155} \text { caffeic acid phenethyl } \\
\text { ester; }^{156} \text { piceatannol; }^{157} \text { dieckol; }{ }^{158} \\
\text { coumestrol }^{159}\end{array}$ \\
\hline
\end{tabular}

(Continued)
Table I (Continued).

\begin{tabular}{|c|c|}
\hline Mechanism of Action & Phytochemicals \\
\hline $\begin{array}{l}\text { Decreasing the phosphorylation of } \\
\text { MAPKs }\end{array}$ & $\begin{array}{l}\text { Sulforaphane; }{ }^{148} \text { sinigrin; }{ }^{150} \\
\text { bisdemethyoxy-curcumin; }{ }^{151} \\
\text { cocoa; }{ }^{155} \text { caffeic acid phenethyl } \\
\text { ester; }{ }^{156} \text { piceatannol; }{ }^{157} \text { dieckol }{ }^{158}\end{array}$ \\
\hline $\begin{array}{l}\text { Inhibiting the phosphorylation of } \\
\text { ERK }\end{array}$ & $\begin{array}{l}\text { Water extract of Hibiscus } \\
\text { sabdariffa L. }{ }^{164}\end{array}$ \\
\hline $\begin{array}{l}\text { Maintaining } \beta \text {-catenin nuclear level } \\
\text { and increasing cyclin DI level }\end{array}$ & Shikonin ${ }^{165}$ \\
\hline $\begin{array}{l}\text { Alteration of GSK3 } \beta \text { abundance } \\
\text { and/or phosphorylation }\end{array}$ & Caffeine; ${ }^{144}$ coumestrol $^{159}$ \\
\hline AMPK activation & Dieckol; ${ }^{158}$ ginsenoside $\mathrm{Rh} 2^{166}$ \\
\hline $\begin{array}{l}\text { Suppressing mRNA expression of } \\
\text { KLF2 }\end{array}$ & Caffeine ${ }^{144}$ \\
\hline $\begin{array}{l}\text { Upregulating KLF4 and KLF5 } \\
\text { expression }\end{array}$ & Dieckol $^{158}$ \\
\hline SIRTI activation & Indole-3-carbinol $^{167}$ \\
\hline
\end{tabular}

adipocytes via the PI3K/AKT and MAPK/ERK signaling pathway. ${ }^{119}$ Moreover, EGCG blocks cell entry into the $\mathrm{S}$ phase and the $\mathrm{S}$ to $\mathrm{G} 2 / \mathrm{M}$ phase transition and suppresses adipogenic cocktail-induced proliferation. ${ }^{120}$ In other studies, using 3T3-L1 cells, EGCG reduced triglyceride accumulation and inhibited the expression of PPAR $\gamma$ and $\mathrm{C} /$ $\mathrm{EBP} \alpha,{ }^{121}$ up-regulated phosphorylation of AMPK and the expression of key Wnt signaling related genes, ${ }^{120}$ and increased energy expenditure and thermogenesis. ${ }^{122}$ In vivo studies on high fat diet-induced obese mice showed that EGCG reduced body weight and plasma lipids, decreased PPAR $\gamma, \mathrm{C} / \mathrm{EBP} \alpha$, SREBP1, aP2, LPL, and FAS in WAT, increased the expression of key genes for lipolysis, $\beta$ oxidation and thermogenesis, ${ }^{123}$ and attenuated fat tissue formation and body weight gain. ${ }^{124}$

\section{Oxysterols}

Oxysterols are oxidized cholesterol metabolites capable of inhibiting the expression of key adipogenic transcripts and adipogenic differentiation. In mouse bone marrow stromal cells, oxysterols inhibited PPAR 22 expression and adipogenic differentiation via Hh signaling pathway, ${ }^{125}$ reduced expressions of key adipogenic transcripts through $\mathrm{Hh}$ and ERK signaling in hen preadipocytes; ${ }^{126}$ and reduced expression of PPAR $\gamma 2$, LPL, and aP2 in MSCs. ${ }^{127}$ 


\section{Resveratrol}

Resveratrol (RSV) is a member of the natural polyphenols found in peanuts, groundnuts, grapevines, and red vines. ${ }^{128}$ It is beneficial for human health due to the cardioprotective effect, anti-inflammatory, and anti-cancer properties. ${ }^{129}$ In studies using 3T3-L1 cells, resveratrol treatment significantly decreased lipid accumulation, down-regulated the expression of C/EBP $\alpha$, LPL, FAS, and SREBP-1c through activation of AMPK, ${ }^{130}$ decreased phosphorylation of MAPKs, and reduced $\mathrm{Rb}$ phosphorylation, ${ }^{131}$ suppressed hormonal-induced AKT activation and cell proliferation, and inhibited cell entry into the $\mathrm{S}$ phase and the $\mathrm{S}$ to the G2/M phase transition. ${ }^{132}$ RSV is the first polyphenolic compound that activates SIRT1, inhibiting proliferation and adipogenic differentiation in human preadipocytes. ${ }^{133}$ A reformulated version of RSV was tested on obese patients where it showed a reduction of blood pressure, serum glucose, and triglyceride levels and increased the number of small adipocytes in subcutaneous adipose tissue. ${ }^{134}$ In another study on patients with T2DM, RSV increased SIRT1 and AMPK expression in muscles. ${ }^{135}$ However, its prophylactic administration to non-obese individuals showed no significant effect on insulin sensitivity, blood pressure, and body composition. ${ }^{136}$ The effect of RSV in humans still needs further investigations using larger cohorts and longer follow-up time.

\section{Gum}

Dietary fibers have recently been recognized as an important ally in the management of hypertension and obesity. Fibers contribute to weight loss, increase insulin sensitivity, have glucose-lowering effects, reduce lipid levels and blood pressure. Dietary gum is rich in fibers and can decrease body weight and blood pressure. Some of the mechanisms include decreased energy intake and adipose tissue accumulation, and downregulation of PPAR- $\gamma$. One meta-analysis of 21 studies with 990 participants summarized results on decreased body weight and waist circumference without effect on BMI. That effect was better with shorter administration of $\leq 15 \mathrm{~g} /$ day gum intake. ${ }^{137}$

\section{Phytosterols}

Phytosterols are components of the cell membrane in plants structurally similar to cholesterol. The primary dietary sources of phytosterols are vegetable oils, nuts, fruits, and seeds. They have been shown to lower cholesterol absorption in animals, possibly due to the chemical similarity with cholesterol causing cholesterol absorption inhibition. ${ }^{138}$ One study showed that glucose levels decreased and insulin levels increased after oral administration of $\beta$-sitosterol in hyperglycemic rats. ${ }^{139}$ Several meta-analyses have concluded that phytosterols use decreases obesity indices, reduces serum lipoprotein and free fatty acid, and improves the lipid profile in humans. A plausible mechanism regarding favorable effects in diabetes might be related to the expression and translocation of GLUT-4 in the skeletal muscle, liver, and white adipose tissue. In vitro studies showed stimulation and phosphorylation of the AMPK pathway enhancing GLUT-4 translocation and expression. ${ }^{140}$

\section{Natural Products and Potential Risks}

As the global use of herbal medicinal products increase, and approximately $80 \%$ of people today depend upon herbal medication as a component of their primary health care, concerns about their safety and efficacy are more recognized. Only medicines have to be proven safe before being released into the market, and herbal products do not fall under that category. They are readily available in the market without prescription without control for purity and potency. The general perception that herbal remedies are natural, safe, and have fewer side effects is misleading. Knowledge of potential adverse effects are limited as herbal medicines are untested, and their use and effect are not monitored. ${ }^{141}$ People often do not consider how natural products may interact with any prescription drug they are taking or with each other. Herbs have been shown to produce a wide range of adverse reactions if taken irregularly, in excessive amounts, or in combination with some medicines. In general, extensive biochemical monitoring and follow-up are necessary for patients taking herbal preparations regularly. ${ }^{142}$

\section{Conclusion}

Over the last few years, adipogenesis is considered an important factor in the pathophysiology of obesity and obesityrelated complications. As a complex process involving various transcriptional cascades, signaling pathways, and molecular mechanisms, significant effort has been made to identify the most suitable adipogenesis regulators to serve as potential therapeutic targets. Most studies are carried out in vitro, revealing additional mechanisms through which conventional medications that are already in use for treating dyslipidemia or T2DM can also affect adipogenesis. Despite the increase in the number of available drugs, obesity prevalence is still rising. That is why several natural products are 
being investigated as anti-obesity agents due to their ability to reduce adipose tissue mass through inhibiting adipogenesis. More evidence indicates that natural products can target more than one known pathway or transcriptional cascade involved in adipogenesis. Our understanding of adipogenesis and its key modulators is still limited. The goal is to increase knowledge on the key adipogenesis determinants' function and relevance to adipose tissue pathophysiology, resulting in new targets for anti-obesity drug development without compromising patients' health. There is still a need to investigate further potential treatment in vivo since their clinical translation is still limited. More studies that will elucidate the best ways for interfering with adipocyte formation, and give precise data on the safety and metabolism of potential antiobesity treatment, will make adipogenesis molecular mechanisms powerful targets in fighting obesity.

\section{Funding}

This research received no external funding.

\section{Disclosure}

The authors report no conflicts of interest in this work.

\section{References}

1. Ambele MA, Dhanraj P, Giles R, Pepper MS. Adipogenesis: a complex interplay of multiple molecular determinants and pathways. Int $J \mathrm{Mol}$ Sci. 2020;21:4283. doi:10.3390/ijms21124283

2. World Health Organization. Obesity and overweight. WHO Newsroom Fact Sheets; 2020. Available from: https://www.who.int/news-room /fact-sheets/detail/obesity-and-overweight. Accessed August 20, 2020.

3. Matsuda M, Shimomura I. Increased oxidative stress in obesity: implications for metabolic syndrome, diabetes, hypertension, dyslipidemia, atherosclerosis, and cancer. Obes Res Clin Pract. 2013;7:e330-e341. doi:10.1016/j.orcp.2013.05.004

4. Schmidt FM, Weschenfelder J, Sander C, et al. Inflammatory cytokines in general and central obesity and modulating effects of physical activity. PLoS One. 2015;10:0121971. doi:10.1371/journal. pone. 0121971

5. Găman MA, Epîngeac ME, Diaconu CC, Găman AM. Evaluation of oxidative stress levels in obesity and diabetes by the free oxygen radical test and free oxygen radical defence assays and correlations with anthropometric and laboratory parameters. World J Diabetes. 2020;11 (5):193-201. doi:10.4239/wjd.v11.i5.193

6. Avgerinos KI, Spyrou N, Mantzoros CS, Dalamaga M. Obesity and cancer risk: emerging biological mechanisms and perspectives. Metabolism. 2019;92:121-135. doi:10.1016/j.metabol.2018.11.001

7. Lighter J, Phillips M, Hochman S, et al. Obesity in patients younger than 60 years is a risk factor for Covid-19 hospital admission. Clin Infect Dis. 2020:ciaa415. doi:10.1093/cid/ciaa415.

8. Simonnet A, Chetboun M, Poissy J, et al.; LICORN and the Lille COVID-19 and Obesity study group. High prevalence of obesity in severe acute respiratory syndrome coronavirus-2 (SARS-CoV-2) requiring invasive mechanical ventilation. Obesity. 2020;28 (7):1195-1199. doi:10.1002/oby.22831
9. De Ferranti S, Mozaffarian D. The perfect storm: obesity, adipocyte dysfunction, and metabolic consequences. Clin Chem. 2008;54:945-955. doi:10.1373/clinchem.2007.100156

10. Feng S, Reuss L, Wang Y. Potential of natural products in the inhibition of adipogenesis through regulation of PPAR $\gamma$ expression and/or its transcriptional activity. Molecules. 2016;21:1278. doi:10.3390/molecules21101278

11. Haczeyni F, Bell-Anderson KS, Farrell GC. Causes and mechanisms of adipocyte enlargement and adipose expansion. Obes Rev. 2018;19:406-420. doi:10.1111/obr.12646

12. Corrales P, Vidal-Puig A, Medina-Gómez G. PPARs and metabolic disorders associated with challenged adipose tissue plasticity. Int J Mol Sci. 2018;19:2124. doi:10.3390/ijms19072124

13. Pellegrinelli V, Carobbio S, Vidal-Puig A. Adipose tissue plasticity: how fat depots respond differently to pathophysiological cues. Diabetologia. 2016;59:1075-1088. doi:10.1007/s00125016-3933-4

14. Rosen ED, Spiegelman BM. What we talk about when we talk about fat. Cell. 2014;156:20-44. doi:10.1016/j.cell.2013.12.012

15. Haider N, Larose L. Harnessing adipogenesis to prevent obesity. Adipocyte. 2019;8:98-104. doi:10.1080/21623945.2019.1583037

16. Charo NL, Rodriguez Ceschan MI, Galigniana NM, Toneatto J, Piwien-Pilipuk G. Organization of nuclear architecture during adipocyte differentiation. Nucleus. 2016;7:249-269. doi:10.1080/ 19491034.2016.1197442

17. Chen Q, Shou P, Zheng C, et al. Fate decision of mesenchymal stem cells: adipocytes or osteoblasts? Cell Death Differ. 2016;23:1128-1139. doi:10.1038/cdd.2015.168

18. Morrison S, McGee SL. 3T3-L1 adipocytes display phenotypic characteristics of multiple adipocyte lineages. Adipocyte. 2015;4:295-302. doi:10.1080/21623945.2015.1040612

19. Gregoire FM, Smas CM, Sul HS. Understanding adipocyte differentiation. Physiol Rev. 1998;78:783-809. doi:10.1152/ physrev.1998.78.3.783

20. Rubin CS, Hirsch A, Fung C, Rosen OM. Development of hormone receptors and hormonal responsiveness in vitro. Insulin receptors and insulin sensitivity in the preadipocyte and adipocyte forms of 3T3-L1 cells. J Biol Chem. 1978;253:7570-7578.

21. Chung SS, Lee JS, Kim M, et al. Regulation of Wnt $/ \beta$-catenin signaling by CCAAT/enhancer binding protein $\beta$ during adipogenesis. Obesity. 2012;20:482-487. doi:10.1038/oby.2011.212

22. Oishi Y, Manabe I, Tobe K, et al. Krüppel-like transcription factor KLF5 is a key regulator of adipocyte differentiation. Cell Metab. 2005;1:27-39. doi:10.1016/j.cmet.2004.11.005

23. Scott RE, Florine DL, Wille JJ, Yun K. Coupling of growth arrest and differentiation at a distinct state in the G1 phase of the cell cycle: GD. Proc Natl Acad Sci USA. 1982;79:845-849. doi:10.1073/pnas.79.3.845

24. Tang QQ, Otto TC, Lane MD. CCAAT/enhancer-binding protein beta is required for mitotic clonal expansion during adipogenesis. Proc Natl Acad Sci USA. 2003;100:850-855. doi:10.1073/ pnas. 0337434100

25. Kim JW, Tang QQ, Li X, Lane MD. Effect of phosphorylation and $\mathrm{S}-\mathrm{S}$ bond-induced dimerization on DNA binding and transcriptional activation by C/EBP $\beta$. Proc Natl Acad Sci USA. 2007;104:1800-1804. doi:10.1073/pnas.0611137104

26. Farmer SR. Transcriptional control of adipocyte formation. Cell Metab. 2006;4:263-273. doi:10.1016/j.cmet.2006.07.001

27. Rosen ED, Walkey CJ, Puigserver P, Spiegelman BM. Transcriptional regulation of adipogenesis. Genes Dev. 2000;14:1293-1307.

28. Tang QQ, Gronborg M, Huang H, et al. Sequential phosphorylation of CCAAT enhancer-binding protein $\beta$ by MAPK and glycogen synthase kinase $3 \beta$ is required for adipogenesis. Proc Natl Acad Sci USA. 2005;102:9766-9771. doi:10.1073/ pnas.0503891102 
29. Tanaka T, Yoshida N, Kishimoto T, Akira S. Defective adipocyte differentiation in mice lacking the $\mathrm{C} / \mathrm{EBP} \beta$ and/or $\mathrm{C} / \mathrm{EBP} \delta$ gene. EMBO J. 1997;16:7432-7443. doi:10.1093/emboj/16.24.7432

30. Ron D, Habener JF. CHOP, a novel developmentally regulated nuclear protein that dimerizes with transcription factors $\mathrm{C} / \mathrm{EBP}$ and LAP and functions as a dominant-negative inhibitor of gene transcription. Genes Dev. 1992;6:439-453. doi:10.1101/gad.6.3.439

31. Moseti D, Regassa A, Kim WK. Molecular regulation of adipogenesis and potential anti-adipogenic bioactive molecules. Int J Mol Sci. 2016;17:124. doi:10.3390/ijms17010124

32. Wang L, Waltenberger B, Pferschy-Wenzig EM, et al. Natural product agonists of peroxisome proliferator-activated receptor gamma (PPAR $\gamma$ ): a review. Biochem Pharmacol. 2014;92:73-89. doi:10.1016/j.bcp.2014.07.018

33. Olefsky JM. Treatment of insulin resistance with peroxisome proliferator-activated receptor $\gamma$ agonists. $J$ Clin Investig. 2000;106:467-472. doi:10.1172/JCI10843

34. Vidal-Puig AJ, Considine RV, Jimenez-Linan $M$, et al. Peroxisome proliferator-activated receptor gene expression in human tissues. Effects of obesity, weight loss, and regulation by insulin and glucocorticoids. J Clin Investig. 1997;99:2416-2422. doi:10.1172/JCI119424

35. Xing H, Northrop JP, Grove JR, Kilpatrick KE, Su JL, Ringold GM. TNF $\alpha$-mediated inhibition and reversal of adipocyte differentiation is accompanied by suppressed expression of PPAR $\gamma$ without effects on Pref-1 expression. Endocrinology. 1997;138:2776-2783. doi:10.1210/endo.138.7.5242

36. Chang E, Kim CY. Natural products and obesity: a focus on the regulation of mitotic clonal expansion during adipogenesis. Molecules. 2019;24:1157. doi:10.3390/molecules24061157

37. Magun R, Burgering BM, Coffer PJ, et al. Expression of a constitutively activated form of protein kinase B (c-Akt) in 3T3-L1 preadipose cells causes spontaneous differentiation. Endocrinology. 1996;137:3590-3593. doi:10.1210/ endo.137.8.8754791

38. De Mora JF, Porras A, Ahn N, Santos E. Mitogen-activated protein kinase activation is not necessary for, but antagonizes, 3T3-L1 adipocytic differentiation. Mol Cell Biol. 1997; 17:6068-6075. doi:10.1128/mcb.17.10.6068

39. Rosen ED, MacDougald OA. Adipocyte differentiation from the inside out. Nat Rev Mol Cell Biol. 2006;7:885-896. doi:10.1038/ nrm2066

40. Chen YY, Lee MH, Hsu CC, Wei CL, Tsai YC. Methyl cinnamate inhibits adipocyte differentiation via activation of the CaMKK2-AMPK pathway in 3T3-L1 preadipocytes. J Agric Food Chem. 2012;60:955-963. doi:10.1021/jf203981x

41. Xi X, Han J, Zhang JZ. Stimulation of glucose transport by AMP-activated protein kinase via activation of p38 mitogen-activated protein kinase. $J$ Biol Chem. 2001;276:41029-41034. doi:10.1074/jbc.M102824200

42. Habinowski SA, Witters LA. The effects of AICAR on adipocyte differentiation of 3T3-L1 cells. Biochem Biophys Res Commun. 2001;286:852-856. doi:10.1006/bbrc.2001.5484

43. Choy L, Derynck R. Transforming growth factor- $\beta$ inhibits adipocyte differentiation by Smad3 interacting with CCAAT/enhancer-binding protein $(\mathrm{C} / \mathrm{EBP})$ and repressing $\mathrm{C} / \mathrm{EBP}$ transactivation function. $J$ Biol Chem. 2003;278:9609-9619. doi:10.1006/bbrc.2001.5484

44. Schulz TJ, Tseng YH. Emerging role of bone morphogenetic proteins in adipogenesis and energy metabolism. Cytokine Growth Factor Rev. 2009;20(5-6):523-531. doi:10.1016/j.cytogfr.2009.10.019

45. Hata K, Nishimura R, Ikeda F, et al. Differential roles of Smad1 and p38 kinase in regulation of peroxisome proliferator-activating receptor gamma during bone morphogenetic protein 2-induced adipogenesis. Mol Biol Cell. 2003;14(2):545-555. doi:10.1091/ mbc.e02-06-0356
46. Suh JM, Gao X, McKay J, McKay R, Salo Z, Graff JM. Hedgehog signaling plays a conserved role in inhibiting fat formation. Cell Metab. 2006;3:25-34. doi:10.1016/j. cmet.2005.11.012

47. Cousin W, Fontaine C, Dani C, Peraldi P. Hedgehog and adipogenesis: fat and fiction. Biochimie. 2007;89:1447-1453. doi:10.1016/j.biochi.2007.08.012

48. Spinella-Jaegle S, Rawadi G, Kawai S, et al. Sonic hedgehog increases the commitment of pluripotent mesenchymal cells into the osteoblastic lineage and abolishes adipocytic differentiation. J Cell Sci. 2001;114(Pt 11):2085-2094.

49. Birsoy K, Chen Z, Friedman J. Transcriptional regulation of adipogenesis by KLF4. Cell Metab. 2008;7:339-347. doi:10.1016/j.cmet.2008.02.001

50. Pei H, Yao Y, Yang Y, Liao K, Wu JR. Kruppel-like factor KLF9 regulates PPAR $\gamma$ transactivation at the middle stage of adipogenesis. Cell Death Differ. 2011;18:315-327. doi:10.1038/ cdd. 2010.100

51. Mori T, Sakaue H, Iguchi H, et al. Role of Kruppel-like factor 15 (KLF15) in transcriptional regulation of adipogenesis. $J$ Biol Chem. 2005;280:12867-12875. doi:10.1074/jbc.M410515200

52. Kim JB, Spiegelman BM. ADD1/SREBP1 promotes adipocyte differentiation and gene expression linked to fatty acid metabolism. Genes Dev. 1996;10:1096-1107. doi:10.1073/ pnas.95.8.4333

53. Reusch JE, Colton LA, Klemm DJ. CREB activation induces adipogenesis in 3T3-L1 cells. Mol Cell Biol. 2000;20:1008-1020. doi:10.1128/mcb.20.3.1008-1020.2000

54. Gupta RK, Arany Z, Seale P, et al. Transcriptional control of preadipocyte determination by Zfp423. Nature. 2010;464:619-623. doi:10.1038/nature08816

55. Huang Y, Das AK, Yang QY, Zhu MJ, Du M. Zfp423 promotes adipogenic differentiation of bovine stromal vascular cells. PLoS One. 2012;7:e47496. doi:10.1371/journal.pone.0047496

56. Rizzo G, Disante M, Mencarelli A, et al. The farnesoid X receptor promotes adipocyte differentiation and regulates adipose cell function in vivo. Mol Pharmacol. 2006;70:1164-1173. doi:10.1124/mol.106.023820

57. Banerjee SS, Feinberg MW, Watanabe M, et al. The Kruppel-like factor KLF2 inhibits peroxisome proliferator-activated receptor- $\gamma$ expression and adipogenesis. J Biol Chem. 2003;278:2581-2584. doi:10.1074/jbc.M210859200

58. Moon YS, Smas CM, Lee K, et al. Mice lacking paternally expressed Pref-1/Dlk1 display growth retardation and accelerated adiposity. Mol Cell Biol. 2002;22:5585-5592. doi:10.1128/ mcb.22.15.5585-5592.2002

59. Hong JH, Hwang ES, McManus MT, et al. TAZ, a transcriptional modulator of mesenchymal stem cell differentiation. Science. 2005;309:1074-1078. doi:10.1126/science.1110955

60. Choi SM, Cho HJ, Cho H, Kim KH, Kim JB, Park H. Stra13/ DEC1 and DEC2 inhibit sterol regulatory element binding protein-1c in a hypoxia-inducible factor-dependent mechanism. Nucleic Acids Res. 2008;36:6372-6385. doi:10.1093/nar/gkn620

61. Tong Q, Tsai J, Tan G, Dalgin G, Hotamisligil GS. Interaction between GATA and the C/EBP family of transcription factors is critical in GATA-mediated suppression of adipocyte differentiation. Mol Cell Biol. 2005;25:706-715. doi:10.1128/ MCB.25.2.706-715.2005

62. Tong Q, Dalgin G, Xu H, Ting CN, Leiden JM, Hotamisligil GS. Function of GATA transcription factors in preadipocyte-adipocyte transition. Science. 2000;290:134-138. doi:10.1126/ science.290.5489.134

63. Picard F, Kurtev M, Chung N, et al. Sirt1 promotes fat mobilization in white adipocytes by repressing PPAR- $\gamma$. Nature. 2004;429:771-776. doi:10.1038/nature02583 
64. Gerhart-Hines Z, Rodgers JT, Bare O, et al. Metabolic control of muscle mitochondrial function and fatty acid oxidation through SIRT1/PGC-1 $\alpha$. EMBO J. 2007;26:1913-1923. doi:10.1038/sj. emboj.7601633

65. Jing E, Gesta S, Kahn CR. SIRT2 regulates adipocyte differentiation through FOXO1 acetylation/deacetylation. Cell Metab. 2007;6:105-114. doi:10.1016/j.cmet.2007.07.003

66. Djuranovic S, Nahvi A, Green R. miRNA-mediated gene silencing by translational repression followed by mRNA deadenylation and decay. Science. 2012;336:237-240. doi:10.1126/science.1215691

67. Koh EH, Chernis N, Saha PK, et al. miR-30a remodels subcutaneous adipose tissue inflammation to improve insulin sensitivity in obesity. Diabetes. 2018;67:2541-2553. doi:10.2337/db17-1378

68. Zhang Z, Wu S, Muhammad S, Ren Q, Sun C. miR-103/107 promote ER stress-mediated apoptosis via targeting the Wnt3a/ beta-catenin/ATF6 pathway in preadipocytes. $J$ Lipid Res. 2018;59:843-853. doi:10.1194/j1r.M082602

69. Arcidiacono B, Chiefari E, Foryst-Ludwig A, et al. Obesityrelated hypoxia via miR-128 decreases insulin-receptor expression in human and mouse adipose tissue promoting systemic insulin resistance. EBioMedicine. 2020;59:102912. doi:10.1016/ j.ebiom.2020.102912

70. Manning P, Munasinghe PE, Bellae Papannarao J, Gray AR, Sutherland W, Katare R. Acute weight loss restores dysregulated circulating MicroRNAs in individuals who are obese. J Clin Endocrinol Metab. 2019;104:1239-1248. doi:10.1210/jc.2018-00684

71. Shin J, He M, Liu Y, et al. SIRT7 represses Myc activity to suppress ER stress and prevent fatty liver disease. Cell Rep. 2013;5:654-665. doi:10.1016/j.celrep.2013.10.007

72. Kurylowicz A. In search of new therapeutic targets in obesity treatment: sirtuins. Int J Mol Sci. 2016;17:572. doi:10.3390/ ijms 17040572

73. Grundy SM. Inflammation, hypertension, and the metabolic syndrome. JAMA. 2003;290:3000-3002. doi:10.1001/ jama.290.22.3000

74. Dias S, Paredes S, Ribeiro L. Drugs involved in dyslipidemia and obesity treatment: focus on adipose tissue. Int $J$ Endocrinol. 2018;2018:2637418. doi:10.1155/2018/2637418

75. Ishihara $\mathrm{Y}$, Ohmori K, Mizukawa M, Hasan AU, Noma T, Kohno M. Beneficial direct adipotropic actions of pitavastatin in vitro and their manifestations in obese mice. Atherosclerosis. 2010;212:131-138. doi:10.1016/j.atherosclerosis.2010.04.019

76. Elfakhani M, Torabi S, Hussein D, Mills N, Verbeck GF, Mo H. Mevalonate deprivation mediates the impact of lovastatin on the differentiation of murine 3T3-F442A preadipocytes. Exp Biol Med. 2014;239:293-301. doi:10.1177/1535370213517614

77. Derosa G, Sahebkar A, Maffioli P. The role of various peroxisome proliferator-activated receptors and their ligands in clinical practice. J Cell Physiol. 2017;233:153-161. doi:10.1002/jcp.25804

78. Rachid TL, Penna-de-Carvalho A, Bringhenti I, Aguila MB, Mandarim-de-Lacerda CA, Souza-Mello V. Fenofibrate (PPARalpha agonist) induces beige cell formation in subcutaneous white adipose tissue from diet-induced male obese mice. Mol Cell Endocrinol. 2015;402:86-94. doi:10.1016/j.mce.2014.12.027

79. La Cava A, Matarese G. The weight of leptin in immunity. Nat Rev Immunol. 2004;4:371-379. doi:10.1038/nri1350

80. Oh YT, Oh KS, Choi YM, et al. Continuous 24-h nicotinic acid infusion in rats causes FFA rebound and insulin resistance by altering gene expression and basal lipolysis in adipose tissue. $\mathrm{Am}$ $J$ Physiol Endocrinol Metab. 2011;300:E1012- E1021. doi:10.1152/ajpendo.00650.2010

81. Fujimori K, Amano F. Niacin promotes adipogenesis by reducing production of anti-adipogenic PGF2 $\alpha$ through suppression of C/EBP $\beta$-activated COX-2 expression. Prostaglandins Other Lipid Mediat. 2011;94:96-103. doi:10.1016/j. prostaglandins.2011.01.002
82. Qi T, Chen Y, Li H, et al. A role for PFKFB3/iPFK2 in metformin suppression of adipocyte inflammatory responses. $J \mathrm{Mol}$ Endocrinol. 2017;59:49-59. doi:10.1530/JME-17-0066

83. Zulian A, Cancello R, Girola A, et al. In vitro and in vivo effects of metformin on human adipose tissue adiponectin. Obes Facts. 2011;4:27-33. doi:10.1159/000324582

84. Chen D, Wang Y, Wu K, Wang X. Dual effects of metformin on adipogenic differentiation of 3T3-L1 preadipocyte in AMPK-dependent and independent manners. Int $J$ Mol Sci. 2018;19:1547. doi:10.3390/ijms 19061547

85. Rojas LB, Gomes MB. Metformin: an old but still the best treatment for type 2 diabetes. Diabetol Metab Syndr. 2013;5:6. doi:10.1186/1758-5996-5-6

86. Lantier L, Fentz J, Mounier R, et al. AMPK controls exercise endurance, mitochondrial oxidative capacity, and skeletal muscle integrity. FASEB J. 2014;28:3211-3224. doi:10.1096/fj.14250449

87. Morano S, Romagnoli E, Filardi T, et al. Short-term effects of glucagon-like peptide 1 (GLP-1) receptor agonists on fat distribution in patients with type 2 diabetes mellitus: an ultrasonography study. Acta Diabetol. 2015;52:727-732. doi:10.1007/s00592-0140710-Z

88. Shao Y, Yuan G, Zhang J, Guo X. Liraglutide reduces lipogenetic signals in visceral adipose of $\mathrm{db} / \mathrm{db}$ mice with AMPK activation and Akt suppression. Drug Des Devel Ther. 2015;9:1177-1184. doi:10.2147/DDDT.S79175

89. Beiroa D, Imbernon M, Gallego R, et al. GLP-1 agonism stimulates brown adipose tissue thermogenesis and browning through hypothalamic AMPK. Diabetes. 2014;63:3346-3358. doi: $10.2337 / \mathrm{db} 14-0302$

90. Challa TD, Beaton N, Arnold M, Rudofsky G, Langhans W, Wolfrum C. Regulation of adipocyte formation by GLP-1/GLP1R signaling. J Biol Chem. 2012;287:6421-6430. doi:10.1074/ jbc.M111.310342

91. El Bekay R, Coin-Araguez L, Fernandez-Garcia D, et al. Effects of glucagon-like peptide- 1 on the differentiation and metabolism of human adipocytes. Br J Pharmacol. 2016;173:1820-1834. doi:10.1111/bph.13481

92. Cragga GM, Pezzutob JM. Natural products as a vital source for the discovery of cancer chemotherapeutic and chemopreventive agents. Med Princ Pract. 2016;25(2):41-59. doi:10.1159/ 000443404

93. Gautam R, Jachak SM. Recent developments in anti-inflammatory natural products. Med Res Rev. 2009;29 (5):767-820. doi:10.1002/med.20156

94. Osadebe PO, Odoh EU, Uzor PF. Natural products as potential sources of antidiabetic drugs. $\mathrm{Br} J$ Pharm Res. 2014;4 (17):2075-2095. doi:10.9734/BJPR/2014/8382

95. Sun NN, Wu TY, Chau CF. Natural dietary and herbal products in anti-obesity treatment. Molecules. 2016;21(10):1351. doi:10.3390/molecules21101351

96. Fu C, Jiang Y, Guo J, Su Z. Natural products with anti-obesity effects and different mechanisms of action. J Agric Food Chem. 2016;64(51):9571-9585. doi:10.1021/acs.jafc.6b04468

97. Park M, Sharma A, Lee HJ. Anti-adipogenic effects of delphinidin-3-O- $\beta$-glucoside in 3T3-L1 preadipocytes and primary white adipocytes. Molecules. 2019;24(10):1848. doi:10.3390/ molecules24101848

98. Rahman N, Jeon M, Kim YS. Delphinidin, a major anthocyanin, inhibits 3T3-L1 pre-adipocyte differentiation through activation of Wnt/ $\beta$-catenin signaling. Biofactors. 2016;42:49-59. doi:10.1002/biof.1251

99. Harmon AW, Patel YM. Genistein inhibits CCAAT/enhancerbinding protein $\beta(\mathrm{C} / \mathrm{EBP} \beta)$ activity and 3T3-L1 adipogenesis by increasing $\mathrm{C} / \mathrm{EBP}$ homologous protein expression. Biochem J. 2002;367:203-208. doi:10.1042/BJ20020300 
100. Hwang J, Park I, Shin J, et al. Genistein, EGCG, and capsaicin inhibit adipocyte differentiation process via activating AMP-activated protein kinase. Biochem Biophys Res Commun. 2005;338:694-699. doi:10.1016/j.bbrc.2005.09.195

101. Zhang M, Ikeda K, Xu J, Yamori Y, Gao X, Zhang B. Genistein suppresses adipogenesis of 3T3-L1 cells via multiple signal pathways. Phytother Res. 2009;23:713-718. doi:10.1002/ptr.2724

102. Lee H, Lee YJ, Choi H, Ko EH, Kim JW. Reactive oxygen species facilitate adipocyte differentiation by accelerating mitotic clonal expansion. $J$ Biol Chem. 2009;284:10601-10609. doi:10.1074/jbc.M808742200

103. Park HJ, Della-Fera MA, Hausman DB, Rayalam S, Ambati S, Baile CA. Genistein inhibits differentiation of primary human adipocytes. J Nutr Biochem. 2009;20:140-148. doi:10.1016/j. jnutbio.2008.01.006

104. Kim M, Park J, Seo M, Jung J, Lee Y, Kan K. Genistein and daidzein repress adipogenic differentiation of human adipose tissue-derived mesenchymal stem cells via $\mathrm{Wnt} / \beta$-catenin signalling or lipolysis. Cell Prolif. 2010;43:594-605. doi:10.1111/ j.1365-2184.2010.00709.x

105. Yang JY, Della-Fera MA, Baile CA. Guggulsterone inhibits adipocyte differentiation and induces apoptosis in 3T3-L1 cells. Obesity. 2008;16:16-22. doi:10.1038/oby.2007.24

106. Yang JY, Della-Fera MA, Rayalam S, Ambati S, Baile CA. Enhanced pro-apoptotic and anti-adipogenic effects of genistein plus guggulsterone in 3T3-L1 adipocytes. Biofactors. 2007;30:159-169. doi:10.1002/biof.5520300303

107. Miller CN, Samuels JS, Azhar Y, Parmar A, Shashidharamurthy R, Rayalam S. Guggulsterone activates adipocyte beiging through direct effects on 3T3-L1 adipocytes and indirect effects mediated through RAW264.7 macrophages. Medicines. 2019;6(1):22. doi:10.3390/medicines6010022

108. Xiong P, Niu L, Talaei S, et al. The effect of berberine supplementation on obesity indices: A dose- response meta-analysis and systematic review of randomized controlled trials. Complement Ther Clin Pract. 2020;39:101113. doi:10.1016/j.ctcp.2020.101113

109. Di Pierro F, Putignano P, Villanova N, Montesi L, Moscatiello S, Marchesini G. Preliminary study about the possible glycemic clinical advantage in using a fixed combination of Berberis aristata and Silybum marianum standardized extracts versus only Berberis aristata in patients with type 2 diabetes. Clin Pharmacol. 2013;5:167-174. doi:10.2147/CPAA.S54308

110. Huang C, Zhang Y, Gong Z, et al. Berberine inhibits 3T3-L1 adipocyte differentiation through the PPAR $\gamma$ pathway. Biochem Biophys Res Commun. 2006;348:571-578. doi:10.1016/j. bbrc.2006.07.095

111. Hu Y, Davies GE. Berberine inhibits adipogenesis in high-fat diet-induced obesity mice. Fitoterapia. 2010;81:358-366. doi:10.1016/j.fitote.2009.10.010

112. Lee YS, Kim WS, Kim KH, et al. Berberine, a natural plant product, activates AMP-activated protein kinase with beneficial metabolic effects in diabetic and insulin-resistant states. Diabetes 2006;55:2256-2264. doi:10.2337/db06-0006

113. Pham TP, Kwon J, Shin J. Berberine exerts anti-adipogenic activity through up-regulation of C/EBP inhibitors, CHOP and DEC2. Biochem Biophys Res Commun. 2011;413:376-382. doi:10.1016/ j.bbrc. 2011.08 .110

114. Ahn J, Lee H, Kim S, Ha T. Curcumin-induced suppression of adipogenic differentiation is accompanied by activation of $\mathrm{Wnt} / \beta$ catenin signaling. Am J Physiol Cell Physiol. 2010;298:C1510C1516. doi:10.1152/ajpcell.00369.2009

115. Lee YK, Lee WS, Hwang JT, Kwon DY, Surh YJ, Park OJ. Curcumin exerts antidifferentiation effect through AMPK $\alpha$ PPAR- $\gamma$ in 3T3-L1 adipocytes and antiproliferatory effect through AMPK $\alpha-C O X-2$ in cancer cells. $J$ Agric Food Chem. 2008;57:305-310. doi:10.1021/jf802737z
116. Kim CY, Le TT, Chen C, Cheng JX, Kim KH. Curcumin inhibits adipocyte differentiation through modulation of mitotic clonal expansion. J Nutr Biochem. 2011;22:910-920. doi:10.1016/j. jnutbio.2010.08.003

117. Tofolean IT, Ganea C, Ionescu D, et al. Cellular determinants involving mitochondrial dysfunction, oxidative stress and apoptosis correlate with the synergic cytotoxicity of epigallocatechin-3-gallate and menadione in human leukemia Jurkat T cells. Pharmacol Res. 2016;103:300-317. doi:10.1016/ j.phrs.2015.12.013

118. Lin Y, Shi D, Su B, et al. The effect of green tea supplementation on obesity: A systematic review and dose-response meta-analysis of randomized controlled trials. Phytother Res. 2020:1-12.

119. Hung PF, Wu BT, Chen HC, et al. Antimitogenic effect of green tea (-)-epigallocatechin gallate on 3T3-L1 preadipocytes depends on the ERK and Cdk2 pathways. Am J Physiol Cell Physiol. 2005;288:C1094-C1108. doi:10.1152/ajpcell.00569.2004

120. Lee H, Bae S, Yoon Y. The anti-adipogenic effects of (-) epigallocatechin gallate are dependent on the Wnt/B-catenin pathway. $J$ Nutr Biochem. 2013;24:1232-1240. doi:10.1016/j.jnutbio.2012.09.007

121. Chan CY, Wei L, Castro-Munozledo F, Koo WL. (-)Epigallocatechin-3-gallate blocks 3T3-L1 adipose conversion by inhibition of cell proliferation and suppression of adipose phenotype expression. Life Sci. 2011;89:779-785. doi:10.1016/j. lfs.2011.09.006

122. Lee MS, Kim Y. Epigallocatechin-3-gallate enhances uncoupling protein 2 gene expression in 3T3-L1 adipocytes. Biosci Biotechnol Biochem. 2009;73:434-436. doi:10.1271/bbb.80563

123. Lee MS, Kim CT, Kim Y. Green tea (-) epigallocatechin-3-gallate reduces body weight with regulation of multiple genes expression in adipose tissue of diet-induced obese mice. Ann Nutr Metab. 2009;54:151-157. doi:10.1159/000214834

124. Klaus S, Pültz S, Thöne-Reineke C, Wolfram S. Epigallocatechin gallate attenuates diet-induced obesity in mice by decreasing energy absorption and increasing fat oxidation. Int $J$ Obes. 2005;29:615-623. doi:10.1038/sj.ijo.0802926

125. Kim WK, Meliton V, Amantea CM, Hahn TJ, Parhami F. 20(S)hydroxycholesterol inhibits PPAR $\gamma$ expression and adipogenic differentiation of bone marrow stromal cells through a hedgehogdependent mechanism. J Bone Miner Res. 2007;22:1711-1719. doi:10.1359/jbmr.070710

126. Kha HT, Basseri B, Shouhed D, et al. Oxysterols regulate differentiation of mesenchymal stem cells: pro-bone and anti-fat. $J$ Bone Miner Res. 2004;19:830-840. doi:10.1359/JBMR.040115

127. Johnson JS, Meliton V, Kim WK, et al. Novel oxysterols have pro-osteogenic and anti-adipogenic effects in vitro and induce spinal fusion in vivo. $J$ Cell Biochem. 2011;112:1673-1684. doi: $10.1002 / j \mathrm{jcb} .23082$

128. Das S, Alagappan VK, Bagchi D, Sharma HS, Maulik N, Das DK. Coordinated induction of iNOS-VEGF-KDR-eNOS after resveratrol consumption: A potential mechanism for resveratrol preconditioning of the heart. Vasc Pharmacol. 2005;42:281-289. doi:10.1016/j.vph.2005.02.013

129. Rubiolo JA, Mithieux G, Vega FV. Resveratrol protects primary rat hepatocytes against oxidative stress damage: activation of the Nrf2 transcription factor and augmented activities of antioxidant enzymes. Eur J Pharmacol. 2008;591:66-72. doi:10.1016/j. ejphar.2008.06.067

130. Chen S, Li Z, Li W, Shan Z, Zhu W. Resveratrol inhibits cell differentiation in 3T3-L1 adipocytes via activation of AMPK. Can J Physiol Pharmacol. 2011;89:793-799. doi:10.1139/y11-077

131. Mitterberger MC, Zwerschke W. Mechanisms of resveratrol-induced inhibition of clonal expansion and terminal adipogenic differentiation in 3T3-L1 preadipocytes. $J$ Gerontol a Biol Sci Med Sci. 2013;68:1356-1376. doi:10.1093/gerona/ glt019 
132. Kwon JY, Seo SG, Yue S, Cheng JX, Lee KW, Kim KH. An inhibitory effect of resveratrol in the mitotic clonal expansion and insulin signaling pathway in the early phase of adipogenesis. Nutr Res. 2012;32:607-616. doi:10.1016/j.nutres.2012.06.014

133. Fischer-Posovszky P, Kukulus V, Tews D, et al. Resveratrol regulates human adipocyte number and function in a Sirt1-dependent manner. Am J Clin Nutr. 2010;92:5-15. doi:10.3945/ajen.2009.28435

134. Timmers S, Konings E, Bilet L, et al. Calorie restriction-like effects of 30 days of resveratrol supplementation on energy metabolism and metabolic profile in obese humans. Cell Metab. 2011;14:612-622. doi:10.1016/j.cmet.2011.10.002

135. Goh KP, Lee HY, Lau DP, Supaat W, Chan YH, Ko AF. Effects of resveratrol in patients with type 2 diabetes mellitus on skeletal muscle SIRT1 expression and energy expenditure. Int J Sport Nutr Exerc Metab. 2014;24:2-13. doi:10.1123/ijsnem.2013-0045

136. Poulsen MM, Vestergaard PF, Clasen BF, et al. High-dose resveratrol supplementation in obese men: an investigator-initiated, randomized, placebo-controlled clinical trial of substrate metabolism, insulin sensitivity, and body composition. Diabetes. 2013;62:1186-1195. doi:10.2337/db12-0975

137. Huang M, Luo J, Luo G, et al. The effect of gum consumption on anthropometric characteristics and cardiac disorders: A systematic review and meta-analysis of randomized controlled trials. Complement Ther Med. 2020;54:102578. doi:10.1016/j. ctim. 2020.102578

138. Salehi-Sahlabadi A, Varkaneh HK, Shahdadian F, et al. Effects of Phytosterols supplementation on blood glucose, glycosylated hemoglobin (HbAlc) and insulin levels in humans: a systematic review and meta-analysis of randomized controlled trials. J Diabetes Metab Disord. 2020;19(1):625-632. doi:10.1007/ s40200-020-00526-z

139. Ivorra M, D'ocon M, Paya M, Villar A. Antihyperglycemic and insulin-releasing effects of beta-sitosterol 3-beta-D-glucoside and its aglycone, beta-sitosterol. Arch Int Pharmacodyn Ther. 1988;296:224-231.

140. Hwang SL, Kim HN, Jung HH, et al. Beneficial effects of beta-sitosterol on glucose and lipid metabolism in L6 myotube cells are mediated by AMP-activated protein kinase. Biochem Biophys Res Commun. 2008;377(4):1253-1258. doi:10.1016/j. bbrc.2008.10.136

141. Ekor M. The growing use of herbal medicines: issues relating to adverse reactions and challenges in monitoring safety. Front Pharmacol. 2014;4:177. doi:10.3389/fphar.2013.00177

142. Abdel-Aziz SM, Aeron A, Kahil TA. Health benefits and possible risks of herbal medicine. In: Garg N, Abdel-Aziz SM, Aeron A, editors. Microbes in Food and Health. Switzerland: Springer International Publishing; 2016:97-116.

143. Abood S, Veisaga M, López L, Barbieri M. Dehydroleucodine inhibits mitotic clonal expansion during adipogenesis through cell cycle arrest. Phytother Res. 2018;32:1583-1592. doi:10.1002/ ptr.6089

144. Kim AR, Yoon BK, Park H, et al. Caffeine inhibits adipogenesis through modulation of mitotic clonal expansion and the AKT/ GSK3 pathway in 3T3-L1 adipocytes. BMB Rep. 2016;49:111-115. doi:10.5483/bmbrep.2016.49.2.128

145. Kim MA, Kang K, Lee HJ, Kim M, Kim CY, Nho CW. Apigenin isolated from Daphne genkwa Siebold et Zucc. inhibits 3T3-L1 preadipocyte differentiation through a modulation of mitotic clonal expansion. Life Sci. 2014;101:64-72. doi:10.1016/j. lfs.2014.02.012

146. Ji SY, Choi KM, Lee YS, et al. Rhamnetin-induced suppression of clonal expansion during early stage of adipogenesis. Arch Pharm Res. 2012;35:1083-1089. doi:10.1007/s12272-012-0616-7
147. Lee Y, Bae EJ. Inhibition of mitotic clonal expansion mediates fisetin-exerted prevention of adipocyte differentiation in 3T3-L1 cells. Arch Pharm Res. 2013;36:1377-1384. doi:10.1007/s12272013-0226-z

148. Choi KM, Lee YS, Sin DM, et al. Sulforaphane inhibits mitotic clonal expansion during adipogenesis through cell cycle arrest. Obesity. 2012;20:1365-1371. doi:10.1038/oby.2011.388

149. Kim SH, Park HS, Lee MS, et al. Vitisin A inhibits adipocyte differentiation through cell cycle arrest in 3T3-L1 cells. Biochem Biophys Res Commun. 2008;372:108-113. doi:10.1016/j. bbrc.2008.04.188

150. Lee HW, Rhee DK, Kim BO, Pyo S. Inhibitory effect of sinigrin on adipocyte differentiation in 3T3-L1 cells: involvement of AMPK and MAPK pathways. Biomed Pharmacother. 2018;102:670-680. doi:10.1016/j.biopha.2018.03.124

151. Lai CS, Chen YY, Lee PS, et al. Bisdemethoxycurcumin inhibits adipogenesis in 3T3-L1 preadipocytes and suppresses obesity in high-fat diet-fed C57BL/6 mice. $J$ Agric Food Chem. 2016;64:821-830. doi:10.1021/acs.jafc.5b05577

152. Gupta A, Singh VK, Kumar D, et al. Curcumin-3,4-Dichloro Phenyl Pyrazole (CDPP) overcomes curcumin's low bioavailability, inhibits adipogenesis and ameliorates dyslipidemia by activating reverse cholesterol transport. Metabolism. 2017;73:109-124. doi:10.1016/j.metabol.2017.05.005

153. Wang L, Li L, Ran X, et al. Ellagic acid reduces adipogenesis through inhibition of differentiation-prevention of the induction of $\mathrm{Rb}$ phosphorylation in 3T3-L1 adipocytes. Evid Based Complement Alternat Med. 2013;2013:287534. doi:10.1155/ 2013/287534

154. Drira R, Chen S, Sakamoto K. Oleuropein and hydroxytyrosol inhibit adipocyte differentiation in 3T3-L1 cells. Life Sci. 2011;89:708-716. doi:10.1016/j.1fs.2011.08.012

155. Min SY, Yang H, Seo SG, et al. Cocoa polyphenols suppress adipogenesis in vitro and obesity in vivo by targeting insulin receptor. Int J Obes. 2013;37:584-592. doi:10.1038/ijo.2012.85

156. Shin SH, Seo SG, Min S, et al. Caffeic acid phenethyl ester, a major component of propolis, suppresses high fat diet-induced obesity through inhibiting adipogenesis at the mitotic clonal expansion stage. J Agric Food Chem. 2014;62:4306-4312. doi:10.1021/jf405088f

157. Kwon JY, Seo SG, Heo YS, et al. Piceatannol, natural polyphenolic stilbene, inhibits adipogenesis via modulation of mitotic clonal expansion and insulin receptor-dependent insulin signaling in early phase of differentiation. $J$ Biol Chem. 2012;287:11566-11578. doi:10.1074/jbc.M111.259721

158. Choi HS, Jeon HJ, Lee OH, Lee BY. Dieckol, a major phlorotannin in Ecklonia cava, suppresses lipid accumulation in the adipocytes of high-fat diet-fed zebrafish and mice: inhibition of early adipogenesis via cell-cycle arrest and AMPK $\alpha$ activation. Mol Nutr Food Res. 2015;59:1458-1471. doi:10.1002/ mnfr.201500021

159. Jang YJ, Son HJ, Ahn J, Jung CH, Ha T. Coumestrol modulates Akt and $W n t / \beta$-catenin signaling during the attenuation of adipogenesis. Food Funct. 2016;7:4984-4991. doi:10.1039/ C6FO01127F

160. Jiang L, Zhang NX, Mo W, et al. Rehmannia inhibits adipocyte differentiation and adipogenesis. Biochem Biophys Res Commun. 2008;371:185-190. doi:10.1016/j.bbrc.2008.03.129

161. Schwarz EJ, Reginato MJ, Shao D, Krakow SL, Lazar MA. Retinoic acid blocks adipogenesis by inhibiting $\mathrm{C} /$ EBPbeta-mediated transcription. Mol Cell Biol. 1997;17:1552-1561. doi:10.1128/mcb.17.3.1552

162. Park UH, Jeong HS, Jo EY, et al. Piperine, a component of black pepper, inhibits adipogenesis by antagonizing PPAR $\gamma$ activity in 3T3-L1 cells. J Agric Food Chem. 2012;60:3853-3860. doi: $10.1021 /$ jf204514a 
163. Li YT, Li L, Chen J, et al. 7-Chloroarctinone-b as a new selective PPAR $\gamma$ antagonist potently blocks adipocyte differentiation. Acta Pharmacol Sin. 2009;30:1351-1358. doi:10.1038/aps.2009.113

164. Kim JK, So H, Youn MJ, et al. Hibiscus sabdariffa L. water extract inhibits the adipocyte differentiation through the PI3-K and MAPK pathway. J Ethnopharmacol. 2007;114:260-267. doi:10.1016/j. jep.2007.08.028

165. Lee H, Bae S, Kim K, et al. Shikonin inhibits adipogenesis by modulation of the WNT/ $\beta$-catenin pathway. Life Sci. 2011;88:294-301. doi:10.1016/j.lfs.2010.12.004
166. Hwan JT, Kim SH, Lee MS, et al. Anti-obesity effects of ginsenoside $\mathrm{Rh} 2$ are associated with the activation of AMPK signaling pathway in 3T3-L1 adipocyte. Biochem Biophys Res Commun. 2007;364:1002-1008. doi:10.1016/j.bbrc.2007.10.125

167. Choi Y, Um S, Park T. Indole-3-carbinol directly targets SIRT1 to inhibit adipocyte differentiation. Int J Obes. 2013;37:881-884 doi:10.1038/ijo.2012.158

Diabetes, Metabolic Syndrome and Obesity: Targets and Therapy

\section{Publish your work in this journal}

Diabetes, Metabolic Syndrome and Obesity: Targets and Therapy is an international, peer-reviewed open-access journal committed to the rapid publication of the latest laboratory and clinical findings in the fields of diabetes, metabolic syndrome and obesity research. Original research, review, case reports, hypothesis formation, expert opinion and commentaries are all considered for publication. The manuscript management system is completely online and includes a very quick and fair peer-review system, which is all easy to use. Visit http://www.dovepress.com/testimonials.php to read real quotes from published authors. 